\title{
İstanbul Basın Ekspres Aksı'nın Gelişme ve Dönüşme Dinamikleri
}

\section{Development and Transformation Dynamics of İstanbul Basın Ekspres Route}

\section{Gülşen Pelin Olcay, (1) Hilal Gözde Nurtekin}

İstanbul Arel Üniversitesi, Mühendislik Mimarlık Fakültesi, Mimarlık Bölümü, İstanbul

\section{ÖZ}

1970'lerde Fordist üretimde yaşanan kriz sanayi sektörünün kentlerin dışına çıkmasına ve sanayi kentlerinin hizmet kentlerine dönüşmesine sebep olmuştur. Gelişmiş ülkelerde kentsel dönüşüm, sanayi sonrası gelişme aşamasının sorunlarını ve özellikle de Post-Fordist dönem dinamiklerinin yol açtığı sosyo-ekonomik ve mekansal çöküntüleri aşmaya yönelik geniş kapsamlı bir yeniden yapılandırma biçimi olarak görülmektedir. Kentlerin sürekli gelişmesi sebebiyle kentin içindeki boşaltılmış sanayi alanlarının dönüştürülerek tekrar kullanılmaları kent için önemli bir hale gelmiştir. Sanayinin uzaklaştığı kentlerde yeni bir mekansal yapılanma başlamıştır. Üretim kentleri olmaları nedeniyle sanayinin kent merkezinde yer aldığı şehirlerde, boşalan sanayi yerleri, yeni kentsel mekan ihtiyaçları için yeniden kullanım gereksinimiyle dönüşmeye başlamışlardır. Eski sanayi yapıları ya da alanları, küreselleşmeye ayak uydurma çabasındaki kentlerin "potansiyel yeni fonksiyon alanları"dır. İstanbul Osmanlı döneminden beri sanayinin kurulduğu ve geliştiği bir merkez olmuştur. Ancak kent merkezinde kalan sanayi yarattı̆̆ı pek çok sorun sebebiyle 1970'lerden beri desantralize olmakta, söz konusu sanayi alanları bir dönüşüm yaşamaktadır. 1970'lerden sonra İstanbul'un merkezinden ayrılan sanayinin geldiği bölgelerden birisi de ulaşım avantajları sebebiyle TEM ve E-5 yollarının çevresi olmuştur. 1980'lerde TEM ve E-5 otoyollarının arasındaki bağlantıyı sürdürmek için inşa edilen Basın Ekspresi Aksı bölgede hızlı arazi kullanımı değişikliklerine yol açmıştır. Bu çalışmanın amacı, İstanbul'daki önemli bir sanayi bölgesinde yer alan Basın Ekspres Aksı'nda sanayinin gelişim ve dönüşüm süreçlerini ve bu süreçlerin dinamiklerini araştırmaktır. Çalışmada halihazır harita verileri kullanılarak Basın Ekspres Aksı'nda sanayinin 1980 öncesi, 1980-1990, 1990-2000, 20002010 yılları arası ve 2010 sonrası olmak üzere 5 dönemde gelişimi ve dönüşümü incelenmiş, birincil ve ikincil kaynaklardan elde edilen bulgularla bu süreçlerin dinamikleri ortaya konmuştur. Araştırma bulgularına göre, bölgede 1970’lerde başlayan sanayileşme,

\section{ABSTRACT}

The crisis experienced in Fordist production in 1970s led to the moving of the industrial sector out of cities, thus causing the transformation of industrial cities into service-based cities. In developed countries, urban transformation is considered as a comprehensive form of restructuring to overcome the problems of post-industrial development as well as the socio-economic and spatial failures caused by the Post-Fordist period. Due to the fact that cities continuously develop, the transformation and the reuse of abandoned industrial areas has become critical for cities. New spatial structuring efforts began in cities where industry moved away. In cities where industry was located in the city center due to the city's manufacturing-focused character, abandoned industrial areas began to transform due to the need for new urban areas. Former industrial areas are the "potential new functional areas" for cities that strive to keep pace with globalization. Since the Ottoman Empire, Istanbul has been a center where industrial facilities were established. However, industrial facilities in the city center have been decentralized since 1970s due to various issues, and these industrial areas have gone under transformation. Since 1970s, due to its advantageous transportation, the vicinity of TEM and E-5 highways was one of the popular destinations for industrial facilities that left the city center. The Basın Ekspres Route, built in 1980s to connect TEM and E-5, caused rapid landuse changes in the area. The purpose of this study is to investigate the development and transformation of industry along the Basın Ekspres Route and the dynamics behind these processes. The development and transformation of industry along the route was examined in 5 periods (namely before 1980, between 1980-1990, between 1990-2000, between 2000-2010 and after 2010) by using base maps. In addition, the dynamics behind these processes were revealed with help of the findings collected from primary and secondary sources. According to the findings of the study, industrialization in the area began in 1970s and gained momentum after

Bu makale Dr. Öğretim Üyesi G. Pelin Olcay danışmanlığında Hilal Gözde Nurtekin tarafından yürütülen, İstanbul Arel Ünviersitesi, Fen Bilimleri Enstitüsü, Mimarlık Anabilim Dalı'nda hazırlanan "Kentin Sanayi Alanlarında Yaşanan Dönüşüm Süreçleri ve Dinamikleri: İstanbul Basın Ekspres Aksı Örneği” isimli yüksek lisans tezinden türetilmiştir.

Geliş tarihi: 23.09.2019 Kabul tarihi: 25.06.2020

Online yayımlanma tarihi: 06.10.2020

Iletişim: Gülşen Pelin Olcay

e-posta: pelinolcay@gmail.com 
1980'lerden sonra hızlanmıştır. Zamanla nüfus ve yapı yoğunluğu artan, kentin merkezinde kalan aksta ve çevresinde 2000'li yıllarda sanayinin imar planları ile desantralizasyonu başlamış, bu bölgede çok sayıda konut, rezidans, ofis ve otel projesi hayata geçirilmiştir. Diğer yandan aksın doğusunda, Bağcılar İlçesi'nin bazı bölgelerinde kirletici olmayan sanayi faaliyetlerine izin verilmektedir. Dolayısıyla aksın yer aldığı bölge halen üretim talebinin ve üretim potansiyelinin devam ettiği bir bölgedir. Bu açıdan Basın Ekspres Aksı ve çevresi hem sanayi kenti hem sanayi sonrası kenti görünümüne sahiptir.

Anahtar sözcükler: Basın Ekspres aksı; sanayileşme; sanayi alanlarının dönüşümü; sanayi sonrası kent. 1980s. Over time, the route remained in the center of the city, and the population in its vicinity increased; thus, in 2000s, the decentralization of industry in the area was initiated with various master plans and numerous residential, office and hotel projects were implemented in this region. On the other hand, the operation of non-polluting industrial activities are allowed in some areas of the Bağcilar District, which lies on the east of the route. Thus, both the demand and the potential for production still remain in the area. In this respect, the Basın Ekspres Route and its surroundings have the appearance of both an industrial and a post-industrial city. Keywords: Basın Ekspres route; industrialization; transformation of industrial zones; post-industrial city.

\section{Giriş}

Gelişmiş ülkelerde 1970'lerde Fordist üretimde yaşanan kriz sanayi sektörünün kentlerin dışına çıkmasına ve sanayi kentlerinin hizmet kentlerine dönüşmesine sebep olmuştur. Gelişmiş ülkelerde kentsel dönüşüm, sanayi sonrası gelişme aşamasının sorunlarını ve özellikle de Post-Fordist dönem dinamiklerinin yol açtığı sosyo-ekonomik ve mekansal çöküntüleri aşmaya yönelik geniş kapsamlı bir yeniden yapılandırma biçimi olarak görülmektedir (Korkmaz, 20I3). Kentlerin sürekli gelişmesi sebebiyle kentin içindeki boşaltılmış sanayi alanlarının dönüştürülerek tekrar kullanılmaları kent için önemli bir hale gelmiştir. Sanayinin uzaklaştığı kentlerde yeni bir mekansal yapılanma başlamıştır. Üretim kentleri olmaları nedeniyle sanayinin kent merkezinde yer aldığı şehirlerde, boşalan sanayi yerleri, yeni kentsel mekan ihtiyaçları için yeniden kullanım gereksinimiyle dönüşmeye başlamışlardır. Eski sanayi yapıları ya da alanları, küreselleşmeye ayak uydurma çabasındaki kentlerin "potansiyel yeni fonksiyon alanları" dır. Bazı toplumsal örgütler kentte barınan insanların sosyal yaşam ve ruh sağlığı açısından parklar ve sosyal aktivite merkezleri önerirken; yatırımcılar ve şirket sahipleri bu tür alanlarda maksimum ticari potansiyelleri olan ofis, alışveriş, eğlence merkezleri veya otel gibi farklı fonksiyon önerilerinde bulunabilmektedir (Hall, 1996). Bununla beraber sanayi alanları kentsel dönüşüm süreçleri sonunda donatı alanları yetersiz, iş ve istihdam olanakları sınırlı yeni sorunlu alanlara da dönüşebilmektedir. Bu sebeple bu alanların gelişim ve dönüşüm süreçlerini irdeleyen araştırmalar yapılması önemlidir.

İstanbul Osmanlı döneminden beri sanayinin kurulduğu ve geliştiği bir merkez olmuştur. Ancak kent merkezinde kalan sanayi, yarattığı pek çok sorun sebebiyle, 1970'lerden beri desantralize' olmakta, bu sanayi alanları bir dönüşüm yaşamaktadır.

Literatürde İstanbul'daki desantralizasyon süreçlerini (Ocakçı, 1989; Sazak, 2002; Öcal, 2006; Yüzer, 2002; Erkut ve Albayrak 2004), sanayi alanlarında desantralizasyon sonrasındaki dönü- şümü ve gelişimi irdeleyen akademik çalışmalar yer almaktadır (Günay, 20l4; Onur ve Alp, 20l8; Sönmez, 20l8). Ancak, hala üretimin devam ettiği ve üretim potansiyeli taşıyan sanayi alanlarının dönüşümü ile ilgili çalışmalar sınırlıdır. Önemli bir ulaşım aksı olması sebebiyle sanayinin gelişim gösterdiği İstanbul Basın Ekspres Aksı da üretim faaliyetlerinin devam ettiği, bununla birlikte dönüşüm yaşayan sanayi alanlarından birisidir. Bu önemli aksta sanayinin gelişimini ve dönüşümünü inceleyen yeterince çalışma bulunmamaktadır.

Bu çalışmanın amacı, Basın Ekspres Aksı'nda sanayinin gelişim ve dönüşüm süreçlerini ve bu süreçlerin dinamiklerini araştırmaktır. Araştırmanın 2 temel sorusu bulunmaktadır; Basın Ekspres Aksı'nda sanayi alanları nasıl gelişmiş ve dönüşmüştür? Bu süreçlerde hangi dinamikler etkili olmuştur?

Çalışmada nitel araştırma yöntemleri kullanılmıştır. Bu kapsamda ilk önce halihazır harita verileri kullanılarak Basın Ekspres Aksı'nda belirlenen çalışma alanında sanayinin 1980 öncesi, 1980-1990, 1990-2000 ve 2000-2010 yıl aralıkları ve 20I0'dan sonraki dönem olmak üzere 5 dönemdeki gelişimi ve dönüşümü incelenmiştir. Bu gelişim ve dönüşüm hava fotoğraflarına işlenerek görselleştirilmiştir. Daha sonra tespit edilen bu gelişim ve dönüşümün sebepleri ve dinamikleri hem birincil hem ikincil veriler kullanılarak ele alınmıştır. Bu dinamiklerin irdelenmesinde kullanılan ikincil veriler imar planları ve bölgeyle ilgili yapılan çeşitli araştırmalardır. Birincil veriler ise ilgili aktörlerle yüz yüze görüşme tekniği ile elde edilmiştir. Elde edilen veriler ışığında, bölgenin gelişim ve dönüşüm süreci ile bu süreçlerin dinamikleri yıllara göre ortaya konmuştur.

1980'lerde TEM ve E-5 otoyollarının arasındaki bağlantıyı sürdürmek için inşa edilen Basın Ekspresi Aksı bölgede hızlı arazi kullanımı değişikliklerine yol açmıştır. İstanbul'un merkezinde yer alan sanayi 1970'lerden sonra İstanbul'un dişına doğru kaymış, merkezden ayrılan sanayinin en çok geldiği bölgelerden birisi de Basın Ekspres Aksı ve çevresi olmuştur.

Metropolitenleşme sürecinin bir parçası olan desantralizasyon, merkez kentin ekonomik ve kentsel fonksiyonlarının yasal belediye sınırları dışına çıkması işlemidir. Desantralizasyon, herhangi bir politik veya kurumsal çerçeveden bağımsız ve bir yoğunluk kademelenmesi içerisinde yer alan teknik ve ekonomik oluşumdur (Sazak, 2002). 
1970'lerde sanayileşmenin başladığı bölgede 1980'lerden sonra sanayileşme hızlanmış, akstaki firma sayısı 1990'larda 40'a yaklaşmıştır. Zamanla nüfus ve yapı yoğunluğu artan ve kentin merkezinde kalan aksta ve çevresinde $2000^{\prime} l i$ yıllarda sanayinin imar planları ile desantralizasyonu başlamıştır. Aksta imar planları ile getirilen Prestij Aksı kullanımı konuttan AVM'ye otelden ofise pek çok karma kullanıma izin vermektedir. Dolayısıyla aksta 2000 'li yıllardan itibaren çok sayıda rezidans, ofis, otel projesi hayata geçirilmiş, lüks konut ve rezidans projeleri için tercih edilen büyük parsellerin varlığı sebebiyle 2010 yılından sonra bu süreç daha da hızlanmıştır. 2019 verilerine göre Basın Ekspres Aksı'nda 8 tane sanayi firması faaliyet göstermektedir. Diğer yandan aksın doğusunda, Bağcılar İlçesi'nin bazı bölgelerinde kirletici olmayan sanayi faaliyetlerine izin verilmektedir. Dolayısıyla aksın yer aldığı bölge halen üretim talebinin ve üretim potansiyelinin devam ettiği bir bölgedir. Bu açıdan Basın Ekspres Aksı ve çevresi, Tümertekin'in (20l4) ifade ettiği gibi, hem sanayi kenti hem sanayi sonrası kenti görünümüne sahiptir.

\section{Materyal ve Metot}

Çalışmada nitel araştırma yöntemleri kullanılımıştır. Araştırma için öncelikle çalışma alanı belirlenmiştir. Basın Ekspres Aksı Bahçelievler, Bağcılar ve Küçükçekmece illçeleri'nden geçmektedir. Bu ilçelerde ve bu ilçelerin her birinin kendi alt bölgelerinde sanayinin gelişimi farklılık göstermektedir. Bu çalışma Basın Ekspres Aksı'na odaklanmaktadır. Basın Ekspres Aksı'nın her iki tarafında yola cephesi olan sanayi parsellerini kapsayan bir çalışma alanı belirlenmiştir. Çalışmada Basın Ekspres Aksı'ndaki gelişim 5 dönemde, 1980 öncesi, 1980-1990, 1990-2000 ve 2000-2010 yıl aralıkları ve 2010'dan günümüze ele alınmıştır. İstanbul Büyükşehir Belediyesi'nden (IBB) edinilen halihazır haritalardan sanayinin çalışma alanındaki gelişimi belirlenen dönemlerde tespit edilmiştir. Hangi sanayi firmalarının bölgede yer seçtiği, daha sonra hangilerinin bölgeden ayrıldığı söz konusu dönemlere ait halihazır haritalar incelenerek belirlenmiş, bu gelişim IBB'nin hava fotoğraflarına işlenerek görselleştirilmiştir.

Daha sonra Basın Ekspres Aksı'nın gelişim ve dönüşüm süreci ikincil veriler üzerinden irdelenmiş, bölgede yapılan imar planları ve bölgeyle ilgili yapılan araştırmalar incelenmiştir. Alanın gelişim ve dönüşüm süreçlerine dair birincil veriler yüz yüze görüşmelerin yapıldığı saha çalışması ile toplanmıştır. Saha çaIışmasında burada hala faaliyet gösteren fabrikalarla, bölgeden ayrılan fabrikaların yerine gelen firmalarla, bölgedeki ilçe belediyeleriyle ve gayrimenkul danışmanlık bürolarıyla görüşülerek bölgenin gelişimine ve dönüşümüne dair bilgiler alınmış, bu gelişmelerin sebep ve sonuçları ile ilgili görüşlerine başvurulmuş, bölgeye hangi fonksiyonların geldiği araştırılmıştır. Elde edilen veriler ışığında, bölgenin gelişim ve dönüşüm süreci ile bu süreçlerin dinamikleri yıllara göre ortaya konmuştur.

\section{Kavramsal ve Kuramsal Çerçeve}

Literatürde sanayinin yer seçimi ve sanayi alanlarının gelişimi ve dönüşümü ile ilgili kapsamlı çalışmalar bulunmaktadır.

\section{I. Sanayileşme ve Sanayinin Yer Seçimi}

Sanayi insanın var oluşuyla başlamış, ilk çağlardaki ilkel aletlerden günümüzde fabrikalarda makineli üretime kadar gelişen bir tarihsel süreç izlemiştir. 18.yy.da Ingiltere'de başlayan sanayi devrimi ile birlikte ortaya çıkan 'sanayileşme' kavramı, üretimin toplulaşması ve üretimde mekanizasyona geçiş sürecinin yanında, daha üst ölçekte, bir ülkede ekonomik faaliyetlerin kırsal üretimden sanayi üretimine kayması şeklinde tanımlanabilir. Ancak sanayileşmeyi yalnızca üretimde mekanizasyon olgusuyla sınırlandırmak yetersiz olacaktır. Çünkü sanayileşme, bu mekanizasyon için gerekli teknolojinin yanında bir ülkede tarımdan ulaşıma, ekonomik yapıdan nüfus dağılımına kadar pek çok dinamiğe bağlı olarak gelişen bir süreçtir. Bu süreci yaşayan ülkelerin kentsel ve kırsal dokusunda ve toplumsal yaşantısında önemli dönüşümler gerçekleşmiştir (Es ve Güloğlu, 2004). Birçok az gelişmiş ve gelişmekte olan ülke, ekonomik kalkınma ile sanayileşmeyi eş anlamlı olarak kabul etmektedir. Sanayileşme ulusal, bölgesel ve yerel ekonomilerde eşit olmayan büyümeye katkıda bulunan, doğrudan ya da dolaylı olarak iş olanağı ve refah yaratan, ekonomik olarak bütünleşmeyi gerçekleştirmede katkısı olan, tüketici talepleri sunan ve yaratan bir süreçtir (Yüzer, 2002).

Sanayi bölgeleri ve sanayi kollarını inceleyen çalışmalardan sanayinin yer seçimini birçok faktörün etkilediği görülmektedir. Temelde, gerek üretim ve gerekse pazarlamanın maliyetleri analiz edilmektedir. Hammaddenin mamul maddeye dönüştürülmesi ve tasarlanan pazar alanlarına sevki için en uygun ortalama maliyet araştırımaktadır. Farklı dönemlerde mekânsal ekonomik analizlerle sanayi alanları yer seçimi kuramlarına katkıda bulunan yaklaşımların bir kısmı maliyeti minimize eden yaklaşımları ön planda tutarken diğer kısmı sanayi yatırımlarının bir arada bulunmasını ve karlılığı maksimize eden yaklaşımlar olmuştur. Bu kapsamda, sanayi yer seçiminde etkili olan faktörler arasında, enerji, hammadde kaynakları, sermaye, arazi, çevre koşulları, su, pazar, işgücü, ulaşım, dış ekonomiler, alt yapı, devlet politikaları gibi değişik faktörler sayılabilir (Tümertekin ve Özgüç, 1997).

\subsection{Sanayi Sonrası Kent (Post-Industrial City) ve Sanayi Alanlarının Dönüşümü}

Sanayileşmeyle birlikte işçi sınıfının ortaya çıkması, kentlerde göç merkezli kentsel sorunların baş göstermeye başlaması kentsel değişim ve dönüşümü başlatan temel olgudur. Sanayi devrimiyle birlikte gelişen toplumların sosyo-ekonomik ve kültürel yapılarındaki değişimler kent mekânları üzerinde de değişimlere neden olmuştur (Dağ ve Özberk, 20I2). Günümüzde gelişmiş ülkelerde kentsel dönüşüm, sanayi sonrası 
gelişme aşamasının sorunlarını ve özellikle de Post-Fordist dönem dinamiklerinin yol açtığı sosyo-ekonomik ve mekansal çöküntüleri aşmaya yönelik geniş kapsamlı bir yeniden yapılandırma biçimi olarak görülmektedir (Korkmaz, 20I3).

1970’ler, küreselleşme, sanayinin dönüşümü ve Keynesyen refah ekonomisinden neoliberal ekonomiye geçiş kavramları ile açılanan bir ekonomik değişimi beraberinde getirmiştir (Dörry vd. 2016). Fordist üretimin 1970'lerin ortalarına doğru krize girmesiyle birlikte, sanayide yaşanan krize bağlı olarak kapanan ya da maliyetlerin ucuz olduğu bölgelere taşınan fabrikaların yerini hizmet sektörü almaya başlamıştır. Bu bağlamda sanayisizleşmeye ${ }^{2}$ ve sanayi kentlerinde çöküşe sebep olan faktörler, fabrikaların kapanması, teknolojinin emeğin yerini alması ve iş olanaklarının kent merkezinden taşınmasıdır (Hall, 1998).

Kentler artık küresel bir ekonomi içerisinde rekabet etmektedir. Eski fonksiyonlarını kaybetmiş olmaları ve bu fonksiyonların yerini yeni fonksiyonların almış olması sebebiyle kentler kendi rollerini yeniden tanımlamaktadırlar. Eski fonksiyonlar mal üretimine dayalı sektörlerken yeni fonksiyonlar bilginin yaratılması, değişimi ve kullanımı ile ilgilidir. Illeri ekonomiler istihdam ve gayri safi milli hasıla payları bakımından imalat sektöründen hizmet sektörüne geçmektedir (Hall, 1997). Önceki sanayi kentleri bir yandan bu değişikliklere adapte olmaya bir yandan yatırımcı çekebilmek için kentler arasındaki rekabette başarılı olmaya çalışmaktadır (Dörry vd. 20I6). "Yarışabilir" küresel sisteme adapte olabilmek için kentler ekonomik ve mekansal yapılarında dönüşüm sürecine girmiştir. Küresel ekonominin getirdiği temel değişiklikler, sanayi sektörünün azalması ve kent dışına çıkması, gelişen teknolojiye paralel olarak hizmet sektörünün gelişmesi ve merkezileşmesidir (Ak, 2008)

Hutton (2004), metropoliten kent merkezlerinin piyasa güçleri tarafından yeniden şekillendirildiğini vurgulamakta, buna bir örnek olarak da merkez kentteki imalatın çökmesi ve hizmet sektörlerinin öne çıkmasını göstermektedir. Sacco ve Blessi (2009) de 1970'lerden beri piyasa güçlerinin pek çok Avrupa, Kuzey Amerika hatta Asya metropollerinin merkezlerini biçimlendirdiğini, sanayi sonrası kentlerinin (post- industrial city) ortaya çıkmasına sebep olduğunu ifade etmektedir. Sanayi sonrası aşamasına geçiş beraberinde eski sanayi imalathanelerinin, fabrikalarının ve depolarının bilgi temelli yeni üretim faaliyetlerine dönüşmesini getirmektedir. Bu yeni alanlarda konut ve ticaret kullanımları da yer almaktadır. 1980'lerden beri pek çok sanayi kenti, küreselleşme süreçlerinin etkisiyle sosyal, ekonomik ve mekânsal değişim yaşamaktadır.

Sanayi sonrası kent, imalatın daraldığı, geleneksel sanayinin yerine hizmet sektörünün geçtiği ve aynı zamanda sanayinin yeniden yapılandırıldığı bir kentsel gelişme aşamasıdır (Hutton, 2004). Sanayi sonrası kent teorisine göre bir ekonomi ne kadar ileriyse, istihdamı ve üretimi de o kadar hizmetlere odaklı olacaktır. Ekonomik faaliyetler malların üretiminden hizmetlerin sunumuna kayacaktır. İmalat sektöründe işler azalacak, hizmet sektöründeki işler istihdamın büyük bölümünü oluşturacaktır (Bell, 1976). 1997 yılında Hall da yeni bir kent biçiminin ortaya çıkmakta olduğunu öne sürmektedir: küresel ağdaki diğer kentlerle bağlantılı, ekonomisi hizmet sektörüne dayalı, bilgiyi girdi olarak kullanan ve çok merkezli bir kent. Hall'a göre (1997), 1960’ların kent modelleri bu yeni koşullara cevap vermemektedir. Artık ticaretin veya imalatın geleneksel faaliyetlerine değil küresel bilgiye dayalı ekonomiyi temel alan yeni kent modellerine ihtiyaç duyulmaktadır. Castells ise (2005), ileri ekonomilerde istihdamın büyük bölümünün hizmet sektörüne yayılmış olduğunun, hizmet sektörünün gayri safi milli hasılaya en büyük katkıyı yaptığının açık olduğunu, ancak bunun imalat sektörlerinin yok olduğu anlamına gelmediğini belirtmektedir. Castells (2005), Cohen ve Zysman ( 1987) pek çok hizmetin imalatla doğrudan ilişkili olduğunun altını çizmektedir. İmalat faaliyetleri ekonominin verimliliği ve rekabet gücü açısından kritik öneme sahiptir. Buradaki karmaşa, ileri ekonomilerle küreselleşme koşulları altında aslında aynı üretim yapısının bir parçası olan kalkınmakta olan ekonomiler arasında suni bir ayrıma gidilmesinden kaynaklanmaktadır. Dolaysıyla 1980'lerde Avrupa'da ya da Amerika'da sanayileşmenin çözüldüğünü iddia edenler dünyanın geri kalanında olup biteni gözden kaçırmaktadır. İmalat sektöründe işler bu dönemde ABD de biraz, Avrupa Birliği'nde ciddi oranda azalırken sanayileşmekte olan ülkelerde I.5 ila 4 kat artmıştır. Öyle ki başka ülkelerde imalat sektöründeki yeni işler, kalkınmış dünyadaki kayıpları büyük ölçüde aşmıştır. Diğer bir ifade ile imalat stratejik sektördür ve hizmet sektörüyle sıkı işbirliği vardır. Bu sebeple imalat sektörünün önemi azalmaz (Castells, 2005).

Slach ve Boruta (2012) İspanya ve İngiltere'de hizmet sektörünün sanayi sonrası kentlerin dönüşümündeki rolüne vurgu yapmaktadır. Hizmet eksenli dönüşümlerle çok sayıdaki kent imalatın olumsuz etkilerini silerek başarılı dönüşümler yaşamış ve kentin imajını yenilemiştir. Örneğin, Milan'ın sanayinin yoğunlaştığı alt bölgelerinde de 1970’lerden beri sanayisizleşme süreci yaşanmakta, bu alanlar yeni konut ve hizmet alanlarına dönüşmektedir (Sacco ve Blessi, 2009). Barcelona ve Londra dünya sistemine ekonomik ve mekânsal anlamda uyum sağlayan iki örnektir. Eski sanayi kentlerinden Barcelona'da bugün bilgi temelli sektörler ön plana çıkarken, Londra bir finans merkezine dönüşmüştür (Ak, 2008). Aslında üretimin kentlerden uzaklaşmasıyla kent içinde kalan sanayi alanları, kentlerin yeniden yapılanma sürecinde yeni kullanım biçimleriyle önemli bir rol üstlenmişlerdir. Kentlerde nüfusun ve kentsel arazi değerinin her geçen gün artması, sanayi alanlarının bulundukları kentsel konumların değerli olması ve ortaya çıkan yeni kentsel mekan ihtiyaçları için elverişli olmaları, bu alanların yeniden kullanılmasını gerekli kılmıştır (Tolga, 2006). Bununla beraber, Scott ve Kühn (20I2) uzun dönem bakıldığında, Batı Avrupa kentlerinde bu dönüşümlerden sonra sanayi dönemindeki 
Tablo I. İncelenen dünya örneklerinin karşılaştırma tablosu

\begin{tabular}{|c|c|c|c|}
\hline Dönüşüm örnekleri & Paddington & Emscher Park & 22@Barcelona \\
\hline $\begin{array}{l}\text { Bölge/kent içindeki } \\
\text { yeri, konumu }\end{array}$ & Londra Merkezi'nin batısı & Kuzey-Ren-Vestfalya Federal Eyaleti & Barcelona kent merkezine yakın \\
\hline Alan büyüklüğü & Yaklaşık 30-32 hektar & 80.000 hektar & 200 hektar \\
\hline Eski fonksiyonu & Küçük sanayiler & Madencilik ve Ağır Sanayi & Endüstriyel alan \\
\hline Yeni fonksiyonu & $\begin{array}{l}\text { Karma kullanım, ofis, konut, } \\
\text { sağlık, eğlence }\end{array}$ & $\begin{array}{l}\text { Ofis, konut, ticari ve kültürel kullanım alanları } \\
\text { İleri teknoloji kullanan sanayi }\end{array}$ & $\begin{array}{l}\text { Konut, yeşil alan, ofis ve otel } \\
\text { Yeni teknoloji tabanlı kullanımlar }\end{array}$ \\
\hline Aktörler & $\begin{array}{l}\text { Kent Konseyi, Geliştirme } \\
\text { Ajansları ve Londra } \\
\text { Hükümet Ajansı }\end{array}$ & $\begin{array}{l}\text { Federal Eyaleti Kentsel Gelişim Bakanlığı, sivil } \\
\text { toplum ve yerel halk }\end{array}$ & Kamu-özel sektör ortaklığı \\
\hline $\begin{array}{l}\text { Finansman } \\
\text { kaynakları }\end{array}$ & $\begin{array}{l}\text { İnşaat firmaları, gayrimenkul } \\
\text { geliştirme ajansları }\end{array}$ & $A B$ fonları, vergiler & $\begin{array}{l}\text { Gayrimenkul geliştirme ajansları, } \\
\text { inşaat firmaları }\end{array}$ \\
\hline
\end{tabular}

Kaynak: Nurtekin, 20I8; Şahin, 2012.

nüfus ve iş sayısının yakalanamadığının altını çizmektedir. Hizmet sektöründeki büyüme sanayisizleşmenin getirdiği iş kayıplarını karşılayamamaktadır. Kentsel dönüşüm fiziksel çevreyi iyileştirmekte, şehrin imajını yenilemekte ve turist çekmektedir. Ama bu şehirler işsizlikle mücadele etmektedir (Scott ve Kühn, 20I2). Eski sanayi alanlarında meydana gelen yapısal değişim yüksek işsizlik oranlarının yanı sıra nüfusun azalmasına neden olmuş, bölgede sosyal entegrasyon ile ilgili önemli sorunlar ortaya çıkmıştır. Konut standartlarının düşük olması ve çok sayıdaki göçmen bu bölgelerde yaşanan sosyal sorunlar arasında yer almaktadır (Franz vd. 2008). Sanayi alanlarının kültürel faaliyetler ekseninde dönüşümü ile ilgili çalışmasında Mommas (2004) bu alanların üretim alanlarından çok tüketim alanlarına dönüştüğünü vurgulamaktadır.

Sanayi alanlarının dönüşümü konusunda farklı ülkelerde farklı uygulamalar söz konusudur. Nurtekin (2018) yaptığı araştırmada Avrupa'nın öncü sanayi ülkelerinden İngiltere, Almanya ve İspanya örneklerini incelemiştir. Bu örneklerin karşılaştırılması Tablo I'de verilmiştir (Nurtekin, 20I8; Şahin, 20I2). Incelenen örneklerde projelerin çok aktörlü dönüşümler olması, özel ve kamu fonlarıyla desteklenmesi göze çarpmaktadır. Ayrıca E.P. ve Barcelona örneklerinde üretim temelinde bir dönüşüm hedeflenmiştir. Geleneksel sanayinin yerini ileri teknoloji kullanan yeni üretim biçimlerinin alması amaçlanmıştır (Nurtekin, 20l8).

Görüldüğü gibi, sanayi alanlarının dönüşümü literatürde ilgi çeken konulardan birisidir. Ancak bu alanların dönüşümü için tek bir formül üretmek mümkün değildir. Bu alanların dönüşümü ülkenin ve bölgenin koşullarına, yasal mevzuatına, sosyal ve ekonomik yapısına göre farklılık gösterir. $\bigcirc$ halde her bölgenin dönüşümünü kendi koşulları içinde değerlendirmek doğru bir yaklaşım olacaktır. Bununla beraber, bu alanların turizm, rekreasyon, kültür, yaratıcı faaliyetler gibi fonksiyonların yer aldığı hizmet bölgelerine, bilgi ve teknoloji temelli yenilikçi sektörlere ve konut alanlarına dönüşmesi çok yaygın bir yöntemdir. Diğer yandan bu bölgelerdeki iş ve istihdam kayıpları önemli sorunlar olarak karşımıza çıkmaktadır. Bu üretim alanlarının tüketim alanlarına dönüşmesi de bir başka risktir. Bu açıdan bakıldığında, kentsel dönüşüm ve planlama süreçleri ile ilgili karar vericilere yardımcı olabilmek için alternatif dönüşüm senaryolarının üretilmesi ve bu senaryoların karşılaştırılması (Boyko vd. 20I2); sanayinin dönüşümünde kaynakların doğru kullanılması açısından sürdürülebilirlik ilkesinin temel ilke olarak benimsenmesi (Hemphill vd. 2004; Williams ve Dair, 2007) bu alanların dönüşümünde önemli bir çerçeve sunabilir.

\section{4. İstanbul'da Sanayinin Gelişimi}

Türkiye'de sanayinin büyük bir kısmı Marmara Bölgesi'nde bulunmaktadır. Osmanlı döneminden beri sanayi yatırımları ülkenin batı bölgelerine yönelmiştir (Ertin, 1998). Osmanlı Devleti'nin başkenti olan İstanbul, yabancı devletlerin farklı zamanlarda Osmanlı toprakları üzerinde kurdukları ulaşım ağları sayesinde hammadde ve işlenmiş ürünlerin taşınması açısından devletin sanayileşmesinin en güçlü gerçekleştiği merkez olmuştur (Doğan, 20।3). Ulaşım olanaklarının yanı sıra, fiziksel ve sosyal alt yapı imkanları, coğrafi avantajları, dünyanın en büyük pazar alanlarından birini oluşturması, gelişmiş ülkelere göre ucuz ve bol işgücü havuzu, işgücünün tecrübesi ve bilgi birikimi, ister yüksek teknolojiye isterse geleneksel üretime

\footnotetext{
Geliş̧miş ülkelerde yaşanan, sanayi sektöründe istihdamın azalması, üretimin sürekli gerilemesi, sanayi sektörünün istihdam ve hasıladaki paylarının azalması olgusu sanayisizleşme olarak adlandırılmaktadır. Sanayisizleşme, endüstriyel kapasite kaybının yanı sıra bir takım ekonomik ve sosyal sonuçları da beraberinde getirmektedir (Meçik ve Afşar, 2015).
} 
dayansın birçok sektörü uzun yıllardır İstanbul'a çekmektedir (Temurçin ve Aldırmaz, 20I7; Olcay, 20I3).

Sanayi devrimine kadar olan süreçte, 15-17. yüzyıllarda Osmanlı sanayi bakımından gelişmiş ülkelerinden biri olarak görülmektedir. İstanbul'daki ilk sanayi yapıları Osmanlı döneminde yapılmıştır. Fatih Sultan Mehmet 1455 yılında Tersane-i Amire (Haliç) ve 1460 Tophane-i Amire'yi (Tophane) kurarak İstanbul'da ilk sanayi hamlesini başlatmıştır (Doğan, 2013). Devlet tarafından, ordunun ve sarayın ihtiyaçları için çeşitli fabrikalar kurulmuştur. Büyük bir çoğunluğu İstanbul ve çevresinde bulunan bu işletmeler içinde en önemlileri, Yedikule'den Küçükçekmece'ye kadar ilerleyen alanda bulunan yünlü, pamuklu dokuma fabrikaları ile Feshane-i Âmire ve demir dökümhaneleridir (Clark, 1992; Yerliyurt, 2008). Yapılan yatırımlarla I800'lü yıllarda İstanbul'da sanayi tesisleri artmıştır. Bu tesislerin İstanbul'da yer seçtiği bölgeler, su ve deniz yolu bağlantısı sebebiyle boğazın iki yakası, Marmara ve Haliç kıyıları ile demiryolu bağlantısı sebebiyle Küçükçekmece, Yedikule, Zeytinburnu ve Bakırköy gibi merkezlerdir (Doğan, 20I3). 20. yy. başlarında da İstanbul'da faaliyet gösteren başlıca sanayi kuruluşlarının kent içindeki yerleri, ağırlıklı olarak Haliç, Boğaz ve Marmara kıyılarındadır (Köksal ve Ahunbay, 2006).

Cumhuriyet Döneminde, Henri Prost'un hazırladığı plan (1937), kentin sonraki mekansal yapısı üzerinde belirleyici bir etki yapmıştır. Bu planın en önemli yanı, Haliç kıyılarını sanayinin yerleşimine açması olmuştur. İstanbul'da imalatın ilerlemesi genel olarak 2. Dünya Savaşı'ndan sonra gerçekleşmiştir. 1950-1980 döneminde İstanbul'un gelişiminde etkin olan en önemli unsur sanayi alanları olmuştur. Sanayi ana ulaşım aksları boyunca gelişerek kentin makroform yapısını önemli ölçüde değiştirmiştir. 1947'de Belediye İmar Müdürlüğü tarafından yayınlanan "İstanbul Sanayi Bölgelerine Ait Talimatname" ve 1949'da ilgili komisyon raporu ile Avrupa Yakası'nda Eyüp, Bakırköy, Kazlıçeşme, Zeytinburnu, Bakırköy, Yeşilköy, Küçükçekmece, Anadolu Yakası'nda Maltepe, Kartal, Pendik ve Kadıköy'de sanayi tesisleri gelişmeye başlamıştır. 1954'te Avrupa Yakası için hazırlanan sanayi planı Şişli ve Kağıthane bölgelerini sanayiye açmıştır. 1955 'te yürürlüğe giren İstanbul Sanayi Planı ise Haliç'teki sanayi yerleşmesini bir ölçüde dondururken, Topkapı-Rami ve Levent'te yeni sanayi alanları belirmiştir (İstanbul Büyükşehir Belediyesi, 2009). 1960 yılı ve öncesinde kurulan işletmelerin önemli bir kısmı Şişli, Zeytinburnu, Beyoğlu, Kağıthane, Esenyurt, Sarıyer, Fatih, Beşiktaş, Maltepe ve Beykoz gibi o dönemin şehirsel alanında yer almaktadır (İstanbul Büyükşehir Belediyesi, 2009; Temurçin ve Aldırmaz, 2017; Tekeli, 1994; Yerliyurt, 2008).

1960'lara doğru sermaye, özel sektöre sağlanan yoğun desteğin de etkisiyle, imalat sanayisine doğru yönelmiştir (Tekeli, 1994). 1966 yılında İstanbul Sanayi Nazım Planı kabul edilmiştir. Bu plana göre Metropoliten alan bütününde birinci, ikinci ve üçüncü sınıf müesseseler belirlenerek, şeker fabrikası, petrol tasfiyehanesi, çimento fabrikaları, gemi inşaat ve tamiri, demiryolu teçhizatı imali gibi bazı birinci sınıf sanayi türleri yasaklanmış, İstinye ve Haliç kıyılarında sanayi alanları iptal edilmiştir (Yüzer, 2002). 1960'lardan sonra, bu planın yetersiz kalması, kentsel rantın ve maliyetlerin yükselmesi sebebiyle büyük sanayi kent çevresine yayılma eğilimine girmiştir. Yakacık-Tuzla-Çayırova-Gebze ve Kartal-Maltepe bölgelerinde sanayi alanları gelişmiştir. Kentin Avrupa Yakası'nda Zeytinburnu ile Bakırköy arasını doldurmuş olan sanayi alanları Sefaköy, Halkalı, Firuzköy, Eyüp, Gaziosmanpaşa, Kâğıthane'ye doğru ilerlemiştir. 1960'lardan sonra sanayinin gelişim gösterdiği diğer ilçeler Tuzla, Küçükçekmece, Esenyurt, Ümraniye ve Bağcılar olmuş, 1980 yılı sonrasında aynı ilçelerde sanayileşme daha da yoğunlaşmıştır (İstanbul Büyükşehir Belediyesi, 2009; Temurçin ve Aldırmaz, 2017).

İstanbul'da yer alan, şehrin içinde olup büyüyemeyen sanayinin 1970'lerden sonra İstanbul'un dışına doğru ilerlediği görülmektedir. Sanayinin ilk yayılma bölgesi olarak İstanbul'un doğusu seçilmiştir. Sanayi tesislerinin yayılması ilk önce Gebze'den başlayarak Kocaeli ve Sakarya'ya doğru olmuş, yayılma daha sonra İstanbul'un batısına, başka bir deyişle Trakya'ya sıçramıştır (Sazak, 2002; Öcal, 2006). Söz konusu yayılma, devletin uyguladığı teşvik politikalarının da etkisiyle 1980'li yıllardan sonra büyük bir ivme kazanmıştır. Öcal'a göre (2006), sanayinin İstanbul dışına desantralizasyonu, İstanbul'un metropolitenleşme sürecinin bir sonucu olarak ele alındığında ekonomik ve teknik; devletin uyguladığı teşvik politikalarını bir sonucu olarak ele alındığında politik bir olgudur (Öcal, 2006). 1980 yıIında üretilen nazım plan bu dönemde sanayi alanlarının gelişiminde etkili olmuştur. Bu planda sanayi alanlarının İstanbul'un gelişme yönünde ilerlediği görülmektedir. Buna ek olarak, Firuzköy, Esenyurt'ta, Halkalı, Kirazlı, Güneşli, İkitelli çevresinde, sınırlı olarak Kemerburgaz vadisinde, Ümraniye, Kurtköy, Sıhlı, Dolayoba, Gebze, Şekerpınar, Dilovası alanlarında yeni sanayi alanları düşünülmüştür (Ocakçı, 1989). 1980'lerden sonraki dönemde, çeşitli desantralizasyon faaliyetleriyle sanayi tesisleri İstanbul'un Anadolu ve Avrupa Yakaları'nda öngörülen ve planlanan Organize Sanayi Bölgeleri'nde toplanmaya çalışılmışır. Bu dönemde ana ulaşım aksları boyunca gelişmiş sanayi alanları, yerlerini ticaret ve hizmet alanlarına bırakmaya başlamış ve kentin Merkezi İş Alanı'nın gelişimini yönlendirmiştir (İstanbul Büyükşehir Belediyesi, 2009).

1990'larda büyük sanayi İstanbul içindeki kısıtlamalar ve büyük ve ucuz arsa nedeniyle il dışına çıkmaya devam etmiştir (Öcal, 2006). Metropoliten alandaki 2 paralel yolun (E-5 ve TEM) ulaşıma açılması, daha geniş alanların ve uzakların yerleşime açılmasını ve desantralizasyon olanaklarını getirmiştir (Sazak, 2002). 1990'। yıllarda sanayi alanları için en önemli sorun şehir merkezinin ortasında bulunan sanayi alanının oluşturduğu çevre kirliliğidir. Eminönü, Beyoğlu, Fatih, Beşiktaş, Şişli, Üskü- 
dar, Bayrampaşa, Zeytinburnu ve Kadıköy ilçelerinde bulunan sanayilerin kent içindeki yoğunluğu bir sorun haline gelmiştir. Kazlıçeşme'nin boşaltılması, Haliç'teki sanayinin yer değiştirmesi bu sorunun neticesinde olmuştur (DPT, 2000).

2009 Yılında onaylanan İstanbul I//00.000 Ölçekli Çevre Düzeni Planı'nda mevcut sanayi alanları işlevleri farklılaştırılacak, mevcut sınırları içinde sağlıklaştırılacak, kapasitesi doyurularak sağlıklaştırılacak sanayi alanları olmak üzere 3 gruba ayrılmıştır. Mevcut sınırlar içerisinde sağlıklaştırılacak bölgeler; Avrupa Yakası'nda Hadımköy, Esenyurt-Kıraç; Anadolu Yakası'nda ise Tuzla OSB Üstü ve Tuzla Tersaneler bölgeleridir. İşlevi farklılaştırılacak sanayi alanları Çatalca, Sultanbeyli, Avcılar gibi havza sınırında yer alan sanayiler; Güneşli, Bahçelievler, Bağcılar, Bayrampaşa, Pendik, Kartal gibi merkezde yer alan sanayiler; Silivri ve Tuzla gibi "çeperlerde yer alan sanayiler" olarak belirlenmiştir. Kapasitesi doyurularak sağIıklaştırılacak sanayi alanları ise farklı bölgelerdeki OSB'lerdir (İstanbul Büyükşehir Belediyesi, 2009).

Çeşitli sebeplerle bir yandan sanayi İstanbul'un dışına kayarken bir yandan da İstanbul zengin işgücü havuzu ve ulaşım avantajları gibi sebeplerle sanayi sektörü için hep çekici olmuş (Ak, 2008), kentte sanayi sektörü sunduğu istihdam olanakları açısından önemini korumuştur (İstanbul Kalkınma Ajansı, 2010). Örneğin, diğer OECD metropollerinin aksine, İstanbul'un ekonomisinde tekstil ve bu sektörün yan sanayisi gibi emek yoğun ve düşük teknolojiye sahip imalat sektörlerinin önemli bir yer tuttuğu gözlenmektedir (OECD, 2008). Sektörde faaliyet gösteren firmalar İstanbul'da yığılmaya devam etmektedir. Tekstil firmaları ağırlıklı olarak Avrupa Yakası'nda ve Güngören, Bağcılar, Küçükçekmece gibi kentin çeperlerindeki ilçelerde yoğunlaşmaktadır (İstanbul Büyükşehir Belediyesi, 2009). Bir başka araştırma 2003 yılından beri İstanbul'da imalat yapmayan, imalat birimlerini yurt içinde ve dışında başka sanayi bölgelerine taşıyan bir hazır giyim firmasının fason imalatın yarısını Mısır'da yarısını İstanbul'da yaptırdığını göstermektedir. Firmanın düzenli çalıştığı dikim firmalarının İstanbul'da öncelikli yer seçim sebebi ise kalifiye işgücüdür. Firmanın fason dikim tedarikçilerinden birisiyle yapılan görüşmede “Bağcılar'daki bir işçi ile Esenyurt'daki bir işçinin ürettiği malın kalitesi bile farklıdır, Bağcılar'daki işçi daha kaliteli ürün üretir. Müşterimizin başka şehirlerde ve ülkelerde üretim tesisleri kurması bizi çok etkilemez, bizim yaptığımız işçiliği onlar yapamazlar" ifadesiyle coğrafyanın ve işgücünün niteliğinin üretim kalitesi üzerindeki etkisini vurgulamaktadır. Aslında burada ifade edilen şey örtük bilgi ve örtük bilginin coğrafyada gömülülüğüdür (Olcay, 20l3). Olcay'a göre (20I3), sektörü bir yandan İstanbul'un dışına iten bir yandan İstanbul'a çeken veya İstanbul'da tutan yerel ve küresel dinamikler bulunmaktadır. İstanbul'un coğrafi avantajlarının, fiziksel ve sosyal alt yapı imkanlarının yanı sıra kentteki işgücünün tecrübesi ve bilgi birikimi özellikle katma değeri yüksek ürünlerle rekabet etmeye çalışan sektör için İstanbul'u avantajlı hale getiren yerel dinamiklerdir.

Kısacası, yapılan araştırma ve çalışmalar, İngiltere, İspanya gibi OECD ülkesi metropollerinden farklı olarak sanayi sektörünün İstanbul'da önemini koruduğunu göstermektedir (Ak, 2008; OECD, 2008). Bir yandan 1970’lerden beri sanayi Eminönü, Kadıköy, Zeytinburnu, Kartal, Silivri gibi pek çok ilçeden desantralize edilirken bir yandan planlarda Hadımköy ve Esenyurt gibi ilçelerde varlığını korumaktadır.

\section{Bulgular}

Bu araştırmada bir yandan üretim faaliyetlerinin devam ettiği bir yandan dönüşüm yaşayan Basın Ekspres Aksı'nın sanayileşme ve dönüşüm süreçleri ile bu süreçlerin dinamiklerine dair bulgular elde edilmiştir.

\section{I. Basın Ekspres Aksı'nın Gelişme ve Dönüşme Dinamikleri}

Basın Ekspres Aksı, Bağcılar, Küçükçekmece ve Bahçelievler ilçelerinden geçen, TEM ve E5 otoyollarını birbirine bağlayan, Yenibosna, Güneşli ve İkitelli ana kavşaklarını içeren bir bağlantı yoludur (Şekil I ve Şekil 2).

Basın Ekspres Aksı kentsel ve bölgesel açısından önemli erişim yolları üzerindedir. Bu bağlantı yolu İstanbul'un iki ana ulaşım aksını birbirine bağlamasının yanı sıra kuzeyinde ve güneyinde İstanbul ekonomisi için çok önemli olan sanayi ve ticaret alanlarını içermektedir.

Basın Ekspres Aksı'nın kuzey-güney aksında sırası ile İkitelli Organize Sanayi Bölgesi, İstoç Toptancılar Çarşısı, küçük sanayi siteleri, sanayi ve depolama alanları, iş merkezleri, rezidanslar ve konut alanları, Kuyumcukent, Atatürk Havalimanı, İstanbul Atatürk Havalimanı Serbest Bölgesi, CNR Fuar Merkezi, Dünya Ticaret Merkezi yer almaktadır. Bu alanda yer alan basın kuruluşları bölgenin gelişmesinde önemli rol oynamış, bölgenin basın aksı olarak kimlik kazanmasına öncülük etmiştir (İstanbul Büyükşehir Belediyesi, 20I3). Başlangıçta seyrek yoğunluklu köylerin yer aldığı bölgenin gelişimi 1970’lerden itibaren hızlanmıştır. Aksın yer aldığı ilçelerin nüfusunun 1970'lerden itibaren sürekli artış kaydettiği, en büyük artışın 1970-1980 yılları arasında yaşandığı anlaşılmaktadır (Tablo 2, Şekil 3). Bağcılar'ın nüfus gelişimi oldukça dikkat çekicidir. İlçenin nüfusu 1970-1980 aralığında 10 kat artmış, 1990'larda diğer iki ilçeyi yakalamıştır.

Bu araştırmada Basın Ekspres Aksı'nın gelişimi 1980 öncesi, 1980-1990, 1990-2000, 2000-2010 ve 2010 yılından günümüzde olmak üzere 5 dönemde ele alınmıştır. Bölgenin bu dönemlerdeki gelişimi Şekil 4'teki hava fotoğraflarında görülmektedir. 


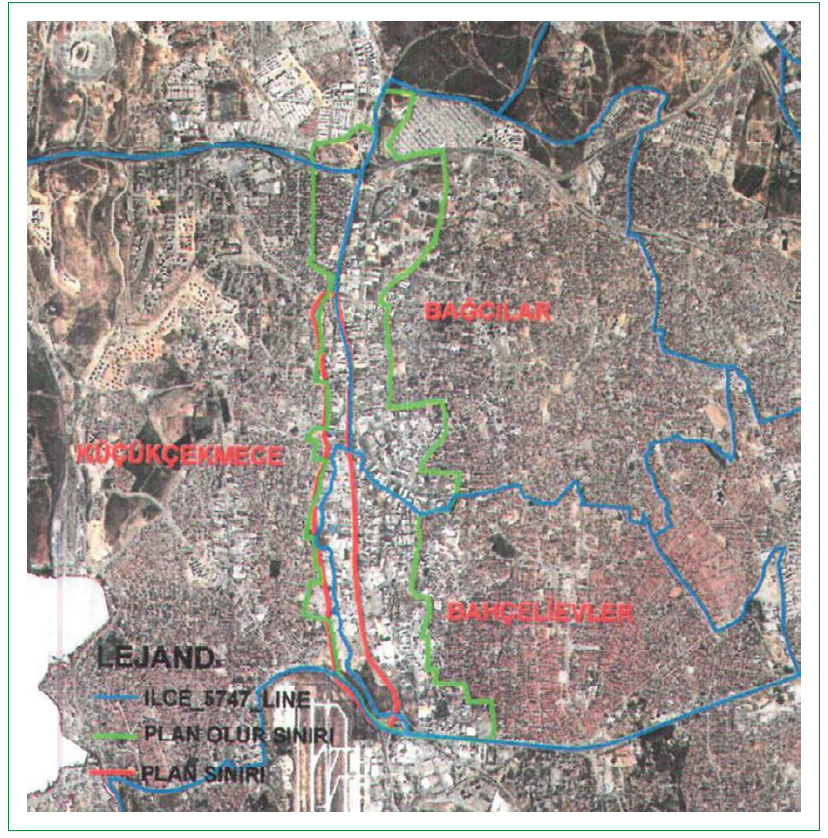

Şekil I.BasınEkspresAksı'nınistanbuliçindekikonumu (Kaynak:I.B.B,20।3).

\section{I.I. 1980 Öncesi Basın Ekspres Aksı - Sanayi Firmalarının} Gelmeye Başlaması

1920'lerde Türkiye Cumhuriyeti'nin Avrupa ile artan ticaret ilişkileri nedeniyle, yetersiz olan demiryolları ve ulaşım hatları göz önüne alınarak ana yollar inşa edilmeye başlanmıştır. Bu yıllarda inşa edilen önemli yollardan biri "Londra Asfaltı"dır. 1960'lı yıllarda doğu-batı doğrultusundaki akışı sürdürmek için yeni bir devlet yolu inşa edilmiştir. "E-5" veya "D-100" karayolu olarak adlandırılan bu yol, 1973'te tamamlanan ve Avrupa ile Asya kıtalarını birbirine bağlayan ilk Boğaziçi Köprüsü ile Ankara, İstanbul ve Edirne şehirleri arasında bir bağ oluşturmaktadır (Delibaş, 20I2).

1954'de Bulgaristan ve Yugoslavya'dan gelen göçmenlerin bir bölümünün bu bölgeye yerleşmesiyle nüfusta ve yeni yerleşim alanlarının oluşmasında bir artış görülmektedir. İstanbul genelindeki yoğun göç ve Küçükçekmece'deki eski çiftliklerin parsellenerek arsa olarak satılması bu araziler üzerinde de düzensiz yapılaşmaya neden olmuştur (Küçükç̧ekmece Belediyesi, 2013). 1950'lere kadar bağlık bahçelik seyrek yerleşimli bir köy olan Bağcılar Bölgesi'nde de 1960'lardan sonra gecekondu yerleşimleri görülmeye başlanmıştır (Bağcılar Belediyesi, 2008). 1970'lerden sonra ise ulaşım olanaklarındaki gelişmeler ve bölgenin kentin görece dışında kalması sebebiyle sanayi firmaları bölgeye gelmeye başlamıştır (Görüşme I, 2018).

\section{I.2. 1980-1990 Döneminde Basın Ekspres Aksı - Hızlı Sa-} nayileşme Dönemi

1970'lerde inşaatına başlanan TEM otoyolunun bölgeden geçen bölümü 1980'lerde büyük ölçüde tamamlanmıştır. TEM, Avrupa ve Asya kıtasını 1988'de tamamlanan İkinci Boğaziçi Köp-

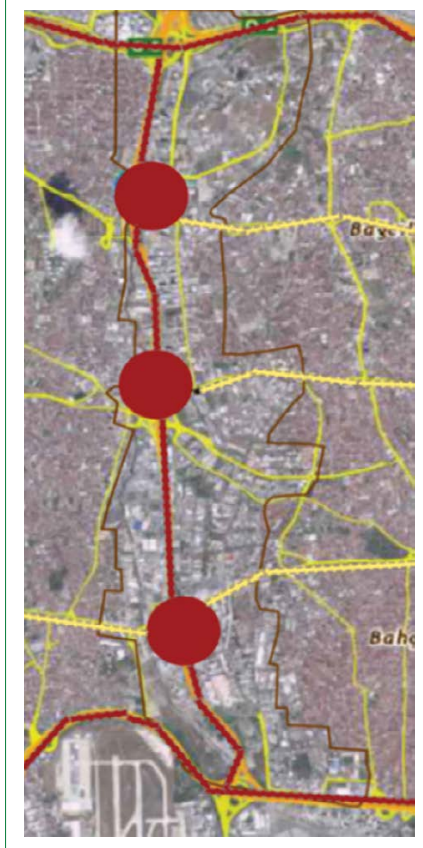

Şekil 2. Basın Ekspres Aksı ve önemli kavşakları (Kaynak: I.B.B, 20I3).

Tablo 2. Basın Ekspres Aksı'ndaki ilçelerin yıllara göre nüfusları

\begin{tabular}{lccc}
\hline & Küçükçekmece & Bağcılar & Bahçelievler \\
\hline 1970 & 77.762 & 9.688 & 57.159 \\
1980 & 192.642 & 95.176 & 171.040 \\
1990 & 352.926 & 304.478 & 340.419 \\
2000 & 594.524 & 556.519 & 478.623 \\
2010 & 695.988 & 738.809 & 590.063 \\
2018 & 770.317 & 734.369 & 594.053 \\
\hline
\end{tabular}

Kaynak: TUiK.

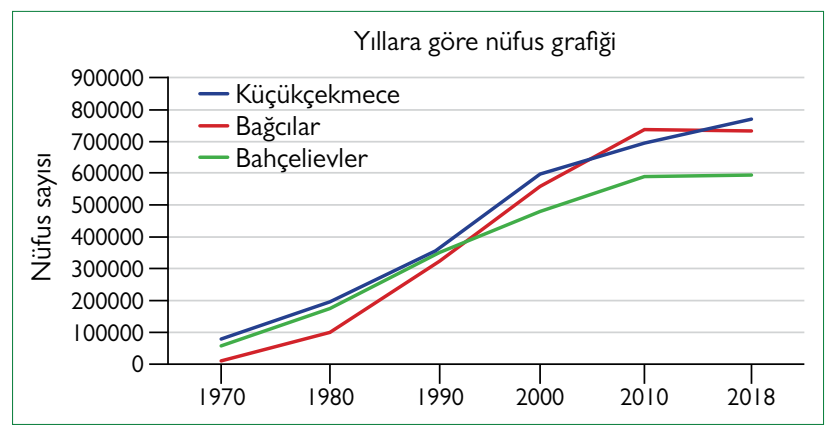

Şekil 3. Basın Ekspres Aksı'ndaki ilçelerin nüfus grafiği (Kaynak: TUiK).

rüsü ile birleştirmiştir (Delibaş, 2012). Ulaşım olanaklarının hızla gelişmesi bu bölgelerin değerini arttırmıştır. Bu dönemde sanayileşme politikaları ihracata dayalı sanayinin gelişmesinde etkili olmuştur. Dönemin iktidar partisinin uluslararası kent söyleminde, İstanbul'un uluslararası sermayeyi çekmesi için 


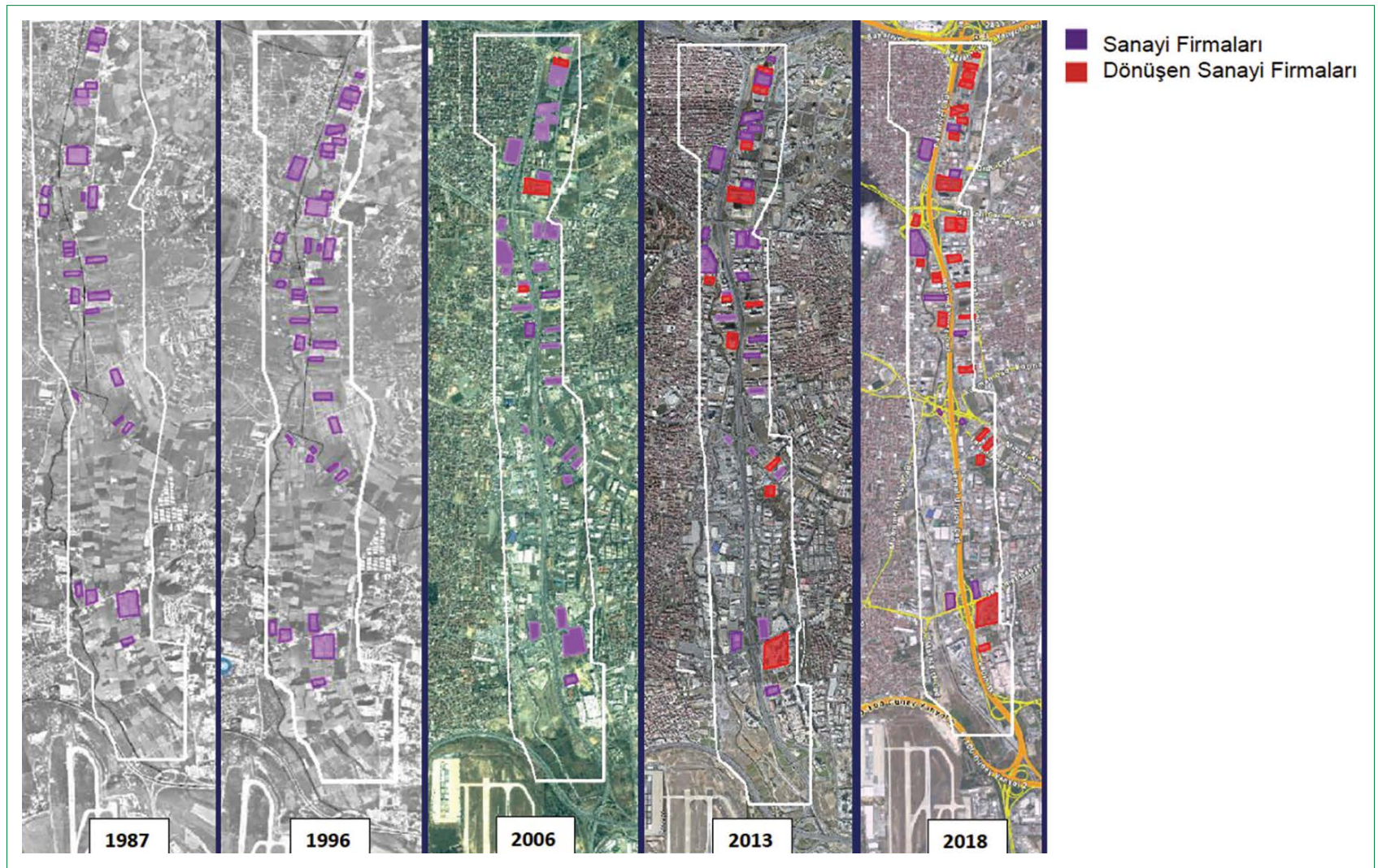

Şekil 4. Basın Ekpres Yolu hava Fotoğrafları, 1987-20।8 (Kaynak: I.B.B. halihazır harita verileri kullanılarak yazarlar tarafından oluşturulmuştur).

uygun altyapının ve yapılı çevrenin gerektiği ifade edilmektedir. Uluslararası kentin mekansal dokusu dönemin iktidar partisinin söyleminde gökdelenler, geniş otoyollar, lüks oteller, alışveriş merkezleri ve lüks konut alanları ile tanımlanmıştır (Öktem, 2006). Yollar genişletilip yoğunluklar artarken; iş, ticaret, sanayi ve yerleşim alanları gibi projeler için yeni firsat alanları oluşturulmuş, bu alanlardaki nüfus ve yatırımlar artmıştır. Bu gelişme sürecinin sonuçlarından biri olan Basın Ekspresi Aksı 1980'lerde iki otoyolun, TEM ve E-5'in arasındaki bağlantıyı sürdürmek için inşa edilmiştir. Böylece, bu alandaki üçlü ulaşım akslarının tamamlanması, Ayamama Deresi havzasında hızlı arazi kullanımı değişikliklerine yol açmıştır. 1980'lerin başında bölgede daha çok tarım alanları bulunmaktayken, 1980‘den sonra TEM ve E-5 bağlantısının tamamlanması, ülkenin değişen sosyal ve ekonomik yapısı sanayinin hızla gelişmesine sebep olmuştur (İstanbul Büyükşehir Belediyesi, 2013).

1980'li yıllarda İstanbul için en önemli sorunlardan birisi şehir merkezinin ortasında bulunan sanayi alanlarının oluşturduğu çevre kirliliğidir. Kent merkezindeki sanayiler orada bulunan yapıları olumsuz etkilemiş, kent içinde yoğunlaşmaları bir sorun haline gelmiştir. Kazlıçeşme'nin boşaltılması, Haliç'teki sanayinin yer değiştirmesi bu sorunun neticesinde olmuştur (DPT, 2000). Merkezden ayrılan sanayinin en çok tercih ettiği bölgelerin arasında Bağcılar yer almaktadır. Şehrin çeperinde kalması sanayi firmalarının Bağcılar'da yer seçmesinde etkili ol- muştur. Bu tercihte şehrin nispeten dışında yer almasının yanı sıra düşük arsa fiyatları da etkili olmuştur (Görüşme 2, 20l8). Örneğin, 1980'lerde Haliç'deki sanayilerin taşınması sürecinde mülk sahiplerine Arsa Ofisi tarafından arsa verilen bölgelerden birisi de Bağcılar'dır. Bu dönemde bu bölgeye yerleşen fabrikaları gören diğer firma sahipleri de zamanla Bağcılar'daki arsalara yönelmişlerdir (Görüşme 3, 20l8).

Bölgede fabrikalar faaliyete geçtiğinde, bu fabrikada çalışan insanlar zamanla bu alanlara yerleşerek mahalleler oluşturmuşlardır. Gelen nüfusla birlikte yapılaşma da artmıştır (Görüşme 2, 20I8).

1980'lerde bölgeye gelen fabrikalar genel olarak tekstil, metal ve kimya sektöründe faaliyet göstermektedir. Halihazır verilerine göre 1987 yılında Basın Ekspres aksında 27 tane fabrika bulunmaktadır. Bu firmaların yerleşimleri Şekil 4'teki hava fotoğraflarında gösterilmiştir.

\section{I.3. 1990-2000 Döneminde Basın Ekspres Aksı - Sanayileş- menin Hızının Azalması}

1970'lerin sonunda başlayan sanayileşme ile gelişen bu bölgeye, 1990'larda sanayi siteleri, ticaret merkezleri ve medya hizmetleri taşınmıştır. Sanayi, ticaret ve konut birimlerinin yoğunlaşması bölgenin hızla büyümesini sağlamıştır. 1990’lı yıllarda da merkezden ayrılan sanayi Güneşli ve Bağcılar'a gelmeye devam etmiştir. Artan sanayileşme ile birlikte gelişen ticaret 
ve konut alanları bölgenin nüfusunun da artmasına sebep olmuştur (Şekil 3).

Aksın içinde kalan farklı alt bölgelerde 1980'li ve 1990'lı yıllarda imar planları yapılmış, daha sonra 298। Sayılı İmar ve Gecekondu Mevzuatına Aykırı Yapılara Uygulanacak Bazı İşlemler ve 6785 Sayılı İmar Kanunu'nun Bir Maddesinin Değiştirilmesi Hakkında Kanun'a göre 1989-1992 yılları arasında islah imar planları yürürlüğe girmiştir. Bağcılar İlçesi'nin 1994 ve 1998 tarihlerinde onaylanan nazım imar planlarında ise Basın Ekspres hattının doğusunda M.İ.A. planlandığı görülmektedir. Bu alanda ticaret ve hizmet fonksiyonları ile Metropoliten Merkez Alanı ve çevre merkezlerle iletişim kurabilen orta ve büyük ölçekli firmaların, büro faaliyetlerinin ve finans kuruluşlarının yer alması hedeflenmiştir (Bağcılar Belediyesi, 2008).

Hali hazır harita verilerine göre, 1996 yılında bölgede 36 fabrika bulunmaktadır (Şekil 4). Bu dönemde bölgeye en çok tekstil firmalarının geldiği görülmektedir. 1987 ve 1996 verileri kıyaslandı̆ında Basın Ekspres Aksı'nda sanayi firma sayısında \%36'lik bir artış görülmektedir. Bu verilerden 1990’larda bölgede sanayi firma sayısının arttığı ancak sanayileşme hızının bir önceki döneme göre azaldığı anlaşılmaktadır. İstanbul genelinde 1990'larda sanayinin merkez alanlardan desantralizasyonu görülürken, merkezden ayrılan bu firmaların da yerleşmesiyle Basın Ekspres Aksı'nda sanayileşme devam etmektedir.

\section{I.4. 2000-2010 Döneminde Basın Ekspres Aksı - Sanayinin} Desantralizasyonu

2000'li yıllara kadar Basın Ekspres Aksı ve çevresi büyük ölçüde sanayi alanı olarak gelişmiştir. İstanbul'un nüfusunun artmasıyla birlikte şehirleşmenin batıya kayması Bağcılar ve Küçükçekmece bölgelerini de etkilemiştir. 1980 ve 1990’larda şehrin çeperinde kalmasından dolayı tercih sebebi olan Basın Ekspres Aksı, 2000'lerde yoğunlaşan nüfus ile birlikte şehir içinde kalmaya başlamış, bölgedeki arsalar değer kazanmıştır. Sanayileşme sürecinde buraya yerleşen insanlar daha sonra bölgedeki fabrikaların olumsuz etkilerine maruz kalmışlardır. Küçükçekmece İlçesi'nde 2004 yılından itibaren (Görüşme 4, 2018), Bağcılar İlçesi'nde 2002 yılından itibaren üretime yönelik bacalı sanayiye ruhsat verilmemiştir. Bölgede sanayinin desantralizasyonu başlamıştır. Bu alanın zamanında kentleşmesine neden olan faktör bölgeyi terk etmek zorunda kalmıştır (Görüşme 2, 20l8).

13.II.2002 yılında onaylanan Bağcılar 1/5000 Nazım İmar Planı'nda Basın Ekspres Aksı'ndaki mevcut gelişimi etkileyecek 2 fonksiyon göze çarpmaktadır; M.I.A. ve Prestij Hizmet Alanları. Prestij Hizmet Alanları'nda uluslararası şirketlerin ve medya yönetim fonksiyonlarının yer alması planlanmıştır. M.İ.A.-I ve M.I.A.-Il bölgelerinden oluşan M.I.A. bölgesinde iş merkezi, ofis, büro, alış-veriş merkezleri, çok katlı mağazalar, çarşı, konaklama tesisleri, sinema, tiyatro, müze, kütüphane, sergi salonu, lokanta, restaurant, gazino, yönetim binaları, banka ve finans kurumları yer alabilecektir. M.I.A.-I Bölgesi, ilçenin 07.03.1994 ve 20.03.1998 onanlı nazım imar planları ile belirlenen M.I.A. sınırlarını kapsayan bölgedir. M.I.A.-II Bölgesi, M.İ.A. sahasının M.I.A.-I bölgesi dışında kalan kısmı olup, M.I.A.-I fonksiyonları ile birlikte çevreyi kirletmeyen, dumansız, atıksız, hizmet ağırıklı bilgisayar üretimi, montajı, matbaa, tekstil, konfeksiyon vb. iş kolları yer alabilir (Bağcılar Belediyesi, 2004).

18.04.2008 tarihinde onaylanan Bağcılar İlçesi I/5000 Revizyon İmar Planı Raporu'na göre; “'Medya Yolu boyunca yer alan sanayi alanlarının ticaret ve hizmet alanlarına dönüşümü teşvik edilmiştir. Aksın üst düzey merkez olarak geliştirilmesi hedefine ulaşmak için 2 temel strateji belirlenmiştir. Birincisi; Medya Yolu Aksının, Medya Yolu Üst Düzey Merkez Özel Proje Alanı adıyla özel proje alanı olarak tanımlanmış olmasıdır. İkincisi, bu alanın küresel sisteme eklemlenme altyapısının oluşturulacağı, hızlı iletişim ağı ve ileri teknoloji ile ağırlıklı olarak uluslar arası ilişkilerin yoğunlaştığı, uluslar arası havaalanına yakın konumu ile özellikle özel sektörün karar ve finans birimlerinin tercih edeceği bir üst düzey merkez olarak tasarlanmasıdır”. Söz konusu nazım imar planında Basın Ekspres Aksı 2002 yılındaki planda olduğu gibi Prestij Hizmet Alanı olarak planlanmıştır. Mevcutta kısmen sanayi tesislerinin yer aldığı bu alanlar, İstanbul Metropoliten alana yapacağı baskının minimum düzeyde tutulacağı uluslararası şirketler ve medya yönetim fonksiyonları, çarşı, konaklama, tesisleri, rezidans konut yapıları, iş merkezi, ofis, büro, alış-veriş merkezleri, çok katlı mağazalar, sinema, tiyatro, müze, kütüphane, sergi salonu, lokanta, restoran, gazino, yönetim binaları, banka ve finans kurumları gibi fonksiyonların yer alacağı alanlar olarak planlanmıştır. Aynı planda Prestij Hizmet Alanları'nın doğu istikametinde ve bu alanlara paralel olarak bulunan alanlarda, bir önceki planda olduğu gibi M.I.A. planlanmış ve aynı fonksiyonlar önerilmiştir (Bağcılar Belediyesi, 2008). Bir önceki plandan farklı olarak M.İ.A. bölgesi M.İ.A. ve M.İ.A.-I bölgesi olarak adlandırılmış, M.I.A-I bölgesinde çevreyi kirletmeyen, dumansız, atıksız, hizmet ağırlıklı bilgisayar üretimi, montajı, matbaa, tekstil, konfeksiyon vb. iş kollarının yer alabileceği belirtilmiştir. Basın Ekspres Aksı'nın Bağcılar alanındaki Prestij Hizmet Alanı ve M.i.A. paftaları Şekil 5'te verilmiştir.

2009 Tarihinde Onaylanan I/I00.000 Ölçekli İstanbul Çevre Düzeni Planı'nda da bu yeni planlanan fonksiyonların korunduğu görünmektedir. Plana göre, Yenibosna Basın Aksı olarak isimlendirilen Yenibosna, Güneşli ve Halkalı-İkitelli ana kavşaklarıyla önemli ulaşım bağlantı noktalarını da içeren İkitelli-Atatürk Havalimanı aksı, 1980'li yıllarda Cağaloğlu'ndan çıkarılan ve son yıllarda aks üzerinde yer seçen, üst düzey yazılı ve sonrasında görsel medya hizmet binalarının etkisiyle bölgesel bir hizmet alanı ve kentsel aktivite merkezi olma potansiyelini taşımaktadır. Bu aks boyunca sanayiden hizmetlere dönüşme eğiliminde olan alan İstanbul Çevre Düzeni 


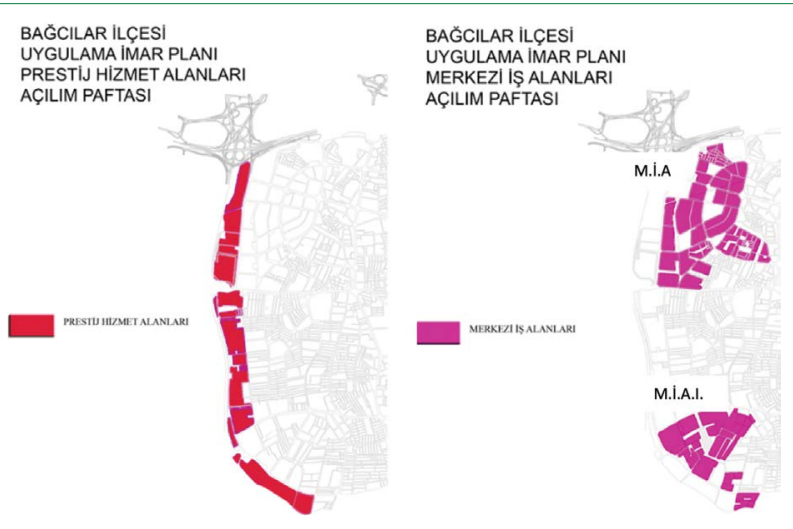

Şekil 5. Basın Ekspres Aksı'nın Bağcılar alanındaki prestij hizmet ve M.i.A. alanları (Kaynak: Bağcılar Belediyesi, 2008).

Planı'nda, İstanbul için belirlenen ilkeler çerçevesinde küresel sisteme eklemlenme altyapısının oluşturulacağı özellikle özel sektörün karar alma ve finans birimlerinin tercih edeceği I. derece merkez olarak belirlenmiştir. Avrupa Yakası'nda Yenibosna Basın Aksı ve Silivri, Anadolu Yakası'nda ise Kartal'daki sanayilerin M.I.A.'nın yükünü azaltacak I.derece merkezlere dönüşmesi planlanmıştır. M.I.A. Bütünleşme Bölgesi olarak tariflenen bölgedeki dönüşüm kapsamında, bu alanlarda yer alacak fonksiyonların kentin siluetini olumsuz etkilememesi; ticaret ve hizmete dönüşmesi öngörülen sanayi alanlarının tür ve özelliklerine göre kent içindeki organize sanayi bölgeleri ile İstanbul Çevre Düzeni Planı'nda belirlenen sanayi alanlarına desantralizasyonu esastır. Mevcutta üretim ve depolama fonksiyonlarını kısmen devam ettiren Yenibosna Basın Aksı, medya kuruluşlarının burada yerleşmesi ile belli bir gelişim ivmesi kazanmıştır. Bu gelişimin yönlendirilmesi ile üst düzey hizmet odaklı bir merkez oluşturulacaktır. Atatürk Havaalanı'na yakınlık avantajı üst düzey hizmet merkezi nitelikli gelişimi destekleyecektir. Diğer yandan, I/I00.000 Ölçekli İstanbul Çevre Düzeni Planı kararlarına göre, aralarında Bağcılar İlçesi'nin Evren ve Bağlar Mahalleleri'nin de yer aldığı İstanbul'un bazı bölgelerinde $1-50$ işgücü büyüklüğüne sahip ve kirletici özelliği düşük sanayi firmalarının mevcut durumunun sağlıklaştırılarak korunması, fakat satış faaliyetini üretimle bir arada yürütmesi, kirleticilik özelliği yüksek özellikle $50+$ işgücü büyüklüğüne sahip sanayi firmalarının bölgeden çıkarılması ve boşalan alanların merkezler kademelenmesi öngörüsü doğrultusunda ticaret-hizmet fonksiyonu ağırıklı kullanımları sağlanmalıdır (İstanbul Büyükşehir Belediyesi, 2009).

Bu periyotta Basın Ekspres Aksı'nın gelişimini, dönüşümünü etkileyen en önemli unsurlardan biri de 2009 yılında Ayamama Deresi'nin taşmasıyla birlikte yaşanan sel felaketidir. Özellikle selden sonra bu aks daha önemli hale gelmiştir. Tüm havza çok geniş bir alanı kapsadığından, sanayi, ticaret, konut, askeri alanlar, kentsel tesisler (eğitim, spor alanları, sağlık birimleri vb.), kentsel yeşil alanlar gibi farklı arazi kullanımlarını içermektedir. Havzadaki arazi kullanımının bu çok yönlü yapısı başta yol inşaatları ile başlamış, iş ve turizm yatırımları ile sürekli gelişme neticesinde meydana gelmiştir. Özellikle, ana yol inşaatları ulaşım ağları etrafında gelişmeyi hızlandırmış ve yoğun nüfuslu ve yüksek oranda kentleşmiş bir yapıya neden olan insanların yatırım fırsatlarına ve göçlerine izin vermiştir. Arazi kullanım analizi kapsamında, havza alanının büyük bir kısmının inşa edildiği ve çoğunlukla sanayi ve yerleşim alanlarının az miktarda yeşil alanla birlikte havza alanını kapladığı görülmektedir (Delibaş, 20I2). Bölgedeki kentleşme hem çevreyi tahrip etmiş hem de zaten yetersiz olan altyapıya fazladan bir yük getirmiştir (Özcan ve Musaoğlu, 2010). Selden sonra dere ıslah çalışmaları yapılmış ve Basın Ekspres Aksı'ndaki dönüşümler hız kazanmıştır. Metropolde yaşanan büyüme de bu bölgedeki sanayi firmalarının desantralizasyonunu beraberinde getirmiştir. Dolayısıyla Basın Ekspres bölgesinin hem yüksek gelir grubunun hem de orta gelir grubunun yaşayacağı bir alan haline gelmesinin temeli bu dönemde atılmıştır.

2006 yılında aksta 3I tane fabrika faaliyet göstermektedir. Fabrikalar yavaş yavaş dönüşmeye başlamıştır. Şekil 4'te 2006 yılındaki Basın Ekspres Aksı'ndaki sanayi firmaları ve dönüşen sanayi firmaları gösterilmiştir. 1996 ve 2006 verileri kıyaslandığında 2006 yılında Basın Ekspres Aksı'ndaki fabrikalarda \% I6'lık bir azalma görülmektedir. Bu veriler 2000'li yıllara gelindiğinde bölgede sanayinin desantrilaze edilmeye başladığını göstermektedir.

\section{I.5. 2010 Yılından Günümüze Basın Ekspres Aksı - Merkezi iş Alanı ve Prestij Alanı Gelişimi}

$\mathrm{Bu}$ dönemde Basın Ekspres Aksı'nın doğusunda ve batısında yeni geliştirilen projeler, eski fabrika ve imalat binaları ile konutlar yer almaktadır. Geçmişte sanayi ve hafif sanayi alanı olarak kullanılan alanların geçirdiği dönüşüm bölgeyi hizmet sektörüne açmış, bu değişim ile birlikte bölgenin değişen yapısı konut sektörü için çekici güç olmuştur. Üst ölçek planlarda İstanbul'daki M.I..A.'nın yükünü azaltacak I.derece merkez olarak planlanan Yenibosna Aksı 'gelecekteki Maslak' olarak ifade edilmeye başlanmıştır (Görüşme 2, 20I8). Basın Ekspres Yolu yeni Maslak Büyükdere hattı olarak şekillendirilmeye çalışımaktaysa da, Serdaroğlu (20l2) bölgenin Maslak Büyükdere Aksı olarak görülmesine karşı çıkmaktadır. Serdaroğlu'na göre (20I2) Büyükdere Aksı, estetik tasarım anlayışından yoksun yüksek katlı bloklar, yetersiz ve niteliksiz otoparklar, yaya ulaşımına imkan vermeyen araç yoğunluğu, planlanmamış parklar ve günün her saati yaşanan kaos ortamı ile aslında Basın Ekspres Aksı'na iyi bir rol model değildir.

Bu dönemde bölgedeki lüks konutların, başka bir deyişle rezidansların sayısı her geçen gün artmıştır. Belli başlı fabrikaların kapanması ve yerine gelen AVM ve konut projeleri Basın Ekspres'in bundan sonraki gelişimine öncülük eden yeni faktörlerdir. Bölgedeki sanayi firmaları ise ya arsalarını satarak 


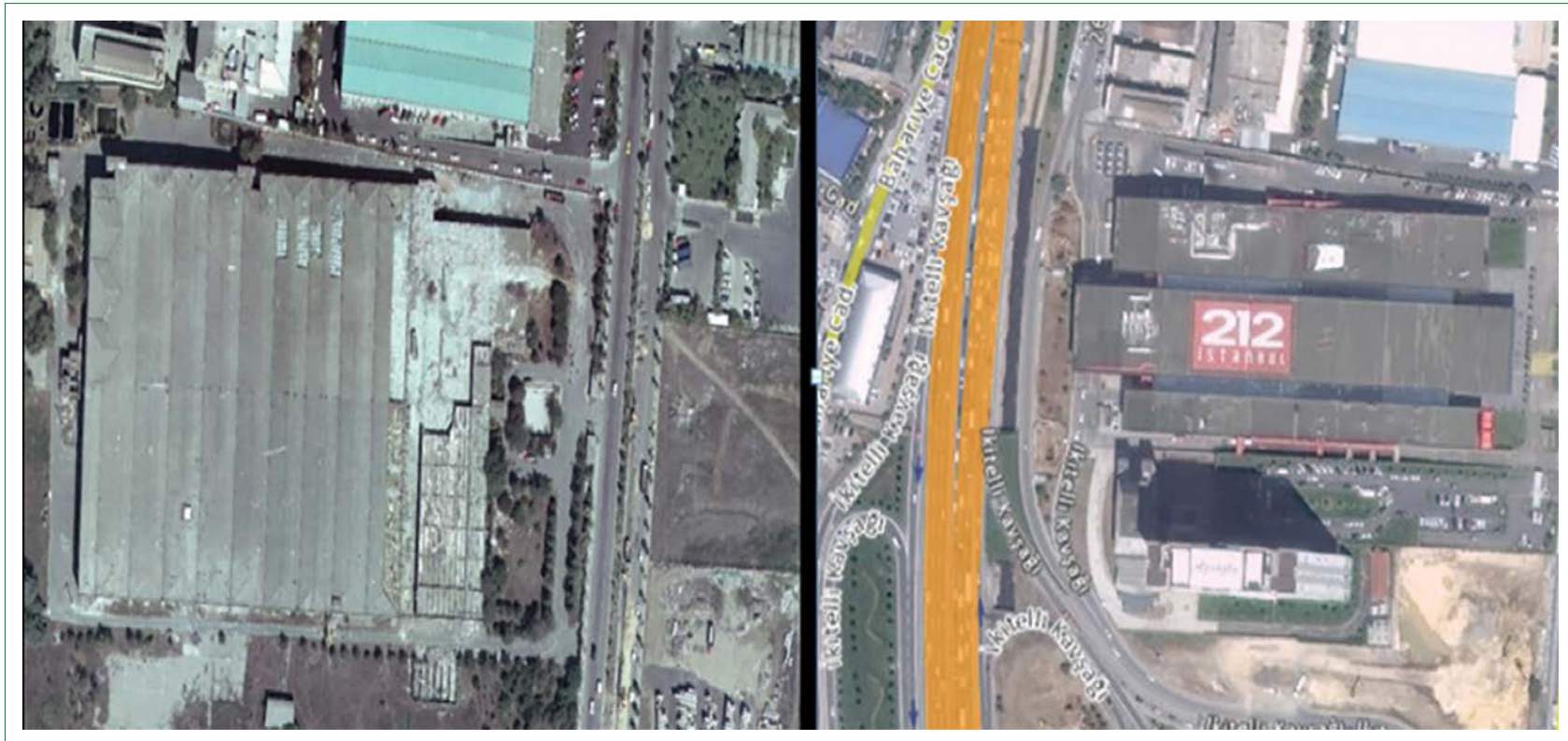

Şekil 6. 2006 ylı Edip İplik Fabrikası ve 2013 yılı 2 I 2 AVM uydu fotoğrafı (Kaynak: Google Haritalar).

bölgeden ayrılmış ya da arsaları üzerinde rezidans, avm veya otel projeleri yapmışlardır (Görüşme 5, 2018). Örneğin, bölgede 197I yılında kurulmuş bir tekstil firması 2006 yılında fabrikasını İstanbul dışındaki başka sanayi bölgesine taşımış, şirketin esas faaliyet konusunu gayrimenkul geliştirme şirketi statüsüne dönüştürmüş, daha sonra Basın Ekspres'deki arazisinde 212 AVM ve 212 My Ofis projelerini hayata geçirmiştir (Şekil 6), (“Edip Gayrimenkul”, t.y). Bazı firmalar ise üretim mekanlarını dükkana veya mağazaya çevirip kiralamışlardır (Görüşme 3, 20l8).

2013 yılında yayınlanan "İstanbul Markalı Konut Sektör Raporu" kapsamında yapılan analize göre markalı konut projeleri açısından Basın Ekspres Aksı ve çevresi en çok değer artışı gösteren bölgelerden biri olarak dikkatleri üzerine çekmektedir. Bu kapsamda 2012-2013 yılları arasında markalı projeler bazında \% 45 prim yapan bölgenin değer artışı oranı hesaplanırken, bölge ve çevresindeki markalı konut projelerinin birim metrekare fiyatlarının bir buçuk yıldaki değişim yüzdesi esas alınmıştır. Bu bağlamda, rapora göre bir buçuk yılda bölgenin takribi değeri markalı projeler bazından \% 45 artmıştır. Bölgenin \% 45 gibi bir değere ulaşmasında ise Küçükçekmece ilçe sınırlarına dâhil olan ve 2012 senesinde satışa çıkan büyük çaplı projelerin etkili olduğu ifade edilmektedir (Milliyet, 20I3). Gayrimenkul sektöründe tanınmış pek çok firma eskiden sanayi bölgesi olan bölgeye yatırım yapmıştır. Basın Ekspres'te birden fazla projesi bulunan inşaat firmalarından bazıları özellikle uluslararası firmalarla ortaklaşa projeler hayata geçirmektedir (Görüşme 6, 2018).

2006 ve 2013 halihazır verileri kıyaslandığında 20I3'te dönüşümün hızlandığı, sanayi firmalarının sayısında \%26'lık bir azal- ma olduğu anlaşılmaktadır (Şekil 4). 2013 yılından sonra aksta dönüşümün hızlanması 2012 yılında yürürlüğe giren 6306 Sayılı Afet Riski Altındaki Alanların Dönüştürülmesi Hakkında Kanunla zamanlama açısından paralellik göstermektedir. Bu da dönüşümde yasanın dolaylı etkisini düşündürmektedir. Çok sayıda gecekondunun yer aldığı Bağcılar İlçesi'nde kentsel yenileme çalışmaları, 2006-2007 yıllarında 5393 Sayılı Belediye Kanunu'nun 73. maddesine istinaden Kentsel Dönüşüm ve Gelişim Projesi Alanlarının belirlenmesi ile başlamıştır. 2012 yılında 6306 Sayılı Afet Riski Altındaki Alanların Dönüştürülmesi Hakkında Kanun'un çıkmasıyla birlikte toplam 53.4 ha alan riskli alan olarak belirlenmiştir. 6306 Sayılı Afet Riski Altındaki Alanların Dönüştürülmesi Hakkında Kanun hem tek bina ölçeğinde hem de alansal ölçekte yenilemeyi mümkün kılmaktadır. İlçede bir yandan büyük parsellerde avan projeye göre kapalı konut projeleri, diğer taraftan tek bina ölçeğinde yapılaşmalar şeklinde bir dönüşüm yaşanmıştır (Gür ve Türk, 20I4). Basın Ekspres Aksı dışında gerçekleşen bu dönüşüm projeleri tüm bölgedeki arazi sahiplerinde arazi değeri artışı beklentisi yaratmıştır. Kent merkezinde kalan ve pek çok büyük parselin yer aldığı Basın Ekspres hattı ve çevresi ise sermayenin iştahını kabartmıştır. Bu büyük parseller inşaat firmaları tarafından özellikle büyük konut projeleri için oldukça avantajlı kabul edilmektedir. Çünkü birden fazla küçük parseli birleştirmek yerine tek büyük parsel üzerinde projeyi hayata geçirmek daha hızlı ve daha sorunsuz olabilmektedir. Tüm bu gelişmeler Baskın Ekspres Aksı'nda bir dönüşüm baskısı yaratmıştır. Özellikle Basın Ekspres Aksı'nın doğusunda, Bağcılar'da yer alan parsellerin büyük olması sebebiyle, dönüşümler hızlanmıştır (Görüşme 7, 20I8). Bu süreçte büyük fabrikaların yanı sıra küçük sanayi firmalarının da yerlerini ticari fonksiyonlar ve konut projeleri almıştır. 
Havalimanına ve CNR Fuar Merkezi'ne yakınlığı ile 20'ye yakın otelin faaliyet gösterdiği bölge, Atatürk Havalimanı'nın kaldırılacak olmasına rağmen yatırımların cazibe merkezi olma özelliğini korumuştur. Otel, konut, rezidans ve ofis projelerinin geliştirilmeye devam ettiği bölgede 2018 yılı itibariyle inşaat, satış ve proje aşamasında birçok proje bulunmaktadır. 2013 yılında aksta 23 fabrika faaliyet gösterirken bu sayı 2018'de 8 'e gerilemiştir. 2013 ve 2018 verileri kıyaslandığında fabrika sayısında \%65'lik bir azalma söz konusudur.

Fakat bu dönüşüme rağmen hala az sayıda fabrika bölgede faaliyetlerine devam etmektedir. Bunun farklı sebepleri bulunmaktadır. Firmalardan birisi başka bir bölgede yatırım planlarının bulunduğunu ancak son birkaç yıldaki ekonomik dalgalanmalardan dolayı sürecin devam ettiğini belirtmektedir. Bununla birlikte 5-10 yıl içerisinde başka bölgeye taşınmayı planlamaktadırlar (Görüşme I, 20l8). Bir başka firma, firma sahibinin bölgeden ayrılma planının olmadığını ifade etmektedir. Çevre kirliliği yaratmadıkları için üretime devam etmekte bir sorun yaşamamaktadırlar. Yetkililer faaliyet alanını değiştirerek hizmet sektöründe faaliyet göstermek istediklerini, etrafta benzer kullanımların artmasından dolayı tereddüt ettiklerini belirtmektedir. Bu firma kapalı alanının bir kısmını kiralayarak diğer kısmında üretim yapmaktadır (Görüşme 3, 20l8).

\section{Tartışma ve Sonuç}

Osmanlı döneminden beri sanayi yatırımları ülkenin batı bölgelerinde yoğunlaşmış, Cumhuriyet döneminde de İstanbul sanayinin en çok yer seçtiği önemli merkezlerden biri olmuştur. Şehrin içinde olup büyüyemeyen sanayi 1970'lerden sonra İstanbul'un dışına doğru kaymaya başlamıştır. Sanayinin desantralizasyonu, hem İstanbul'un metropolitenleşme sürecinin, hem devletin uyguladığı teşvik politikalarının hem de imar planı kararlarının bir sonucudur. Bu süreçlerde merkezden ayrılan sanayinin en çok geldiği bölgelerden birisi de Basın Ekspres Aksı ve çevresi olmuştur. Bu çalışma Basın Ekspres Aksı'nın sanayileşme ve dönüşüm süreçlerini ve bu süreçlerin dinamiklerini ele almaktadır. Aksın gelişme ve dönüşme dinamikleri Tablo 3'te verilmiştir.

1980'lerde inşa edilen Basın Ekspres Aksı TEM ve E-5 yollarını birleştiren önemli bir ulaşım bağlantı yoludur. Başlangıçta kırsal nitelikli yerleşmelerin ve gecekonduların olduğu bölgeye 1970'lerin sonunda sanayi firmaları gelmeye başlamıştır. Önemli ulaşım akslarının üzerinde yer alması, kent merkezinin nispeten dışında kalması, arazinin ucuz olması, hammaddeye yakınlık, sanayi firmalarının bu bölgede yer seçmesinde etkili olmuştur. İmar planlarındaki desantralizasyon kararları ve Arsa Ofisi'nin merkezden ayrılan sanayi firmalarına bu bölgeden yer vermesi de bu süreci desteklemiştir. Sanayinin gelişmesi, buna paralel olarak sanayi firmalarında çalışanların ailelerinin bölgeye yerleşmeye başlaması bölgede hızlı bir nüfus artışını da beraber getirmiştir. 1990'lı yıllardan itibaren imar planlarında aksın doğusunda M.İ.A. fonksiyonları, dolayısıyla ticaret ve hizmet sektörleri teşvik edilmiştir. 2000'li yıllara gelindiğinde bölgede nüfus yoğunluğu gittikçe artmış, üstelik kentin büyümesi ile bölge kent merkezinde kalmıştır. Basın Ekspres Aksı sanayinin getirdiği çevre kirliliği, nüfus ve yapı yoğunluğu sorunları ile yüz yüze kalmış, yaklaşık 20 yıl sonra sanayi bölgeden plan kararları ile desantralize edilmeye başlanmıştır. Bu planlarda aks üst düzey merkez ve M.I.A.'nın yükünü azaltacak I. Derece merkez olarak planlanmıştır. Bu planların da etkisiyle bölgedeki sanayi sektörünün desantralizasyonu ve hizmet sektörüne dönüşüm hızlanmıştır. 2010'dan sonra arazi değerlerindeki artış ve büyük sanayi parsellerinin yatırımcıların iştahını kabartması aks üzerindeki dönüşüm baskısını artırmıştır.

Desantralizasyon sürecinde bölgedeki sanayiciler ya firmalarını taşıyarak parsellerini satmış, ya fabrikalarını farklı fonksiyonlar için kiralamışlar ya da bu parseller üzerinde otel, AVM veya büyük konut projesi inşaatları yapmışlardır. Günümüzde sadece 8 sanayi tesisinin faaliyet gösterdiği çalışma alanında çok sayıda büyük konut projesi, rezidans, AVM, ofis ve otel yer almaktadır. Bununla beraber aksın doğusunda, Bağcılar İlçesi'nin bazı bölgelerinde çevreyi kirletmeyen atölye ve küçük imalata izin verilmektedir. Bu plan kararı, gelişmiş metropollerden farklı olarak sanayi sektörünün İstanbul'da ve Bağcılar'da önemini koruduğuna dair bulgularla (Olcay, 20l3; Ak, 2008) paralellik göstermektedir. İstanbul'da Basın Ekspres Aksı ve çevresi bir yandan dönüşen bir yandan üretimin devam ettiği bir bölge haline gelmiştir. Temurçin ve Aldırmaz’a göre (20I7) gelişmiş ülkelerde sanayi-şehir ilişkisi gittikçe zayıflarken, gelişmekte olan ülkelerde bu bağ her geçen gün daha da güçlenmektedir. Sanayi faaliyetlerinin gittikçe pazara ve ucuz-bol işgücüne bağımlı hale gelmesi, şehirle bütünleşmesini zorunlu kılmaktadır. Bu durum uygulanan politikalara ve planlamalara karşın hâlâ İstanbul'un, ülkemizde sanayinin en yoğun olduğu bölgeyi oluşturmasının temel nedenlerindendir. Tümertekin (20I4) İstanbul'un sanayi öncesi şehir, sanayi şehri ve günümüzde hızla artmakla birlikle, sanayi sonrası şehir görünümlerinin tamamına sahip olduğunu ifade etmektedir. Günümüzde bir sorun olarak görülen bu durum, gelecekte şehrin mekânsal yapısında oluşturacağı olası etkiler açısından dikkate değerdir. Dolayısıyla aksın yer aldığı bölge halen üretim talebinin ve üretim potansiyelinin devam ettiği bir bölgedir. Bu açıdan Basın Ekspres Aksı ve çevresi, Tümertekin'in ifade ettiği gibi, hem sanayi kenti hem sanayi sonrası kenti görünümüne sahiptir.

Basın Ekspres Aksı'ndaki dönüşümde herhangi bir dönüşüm projesi uygulanmamıştır. Ancak bu dönüşümde imar planları önemli bir araç olmuştur. İmar planı koşullarına göre bölge yeniden şekillenmektedir. Plan yapım süreçlerine aktörlerin ve paydaşların katılımı söz konusu olmamıştır. Bununla beraber, yatırımcılar bölgede planlanan M.I.A. ve Prestij Aksı gibi fonksiyonların içerdiği karma kullanım alternatiflerinden kendi 


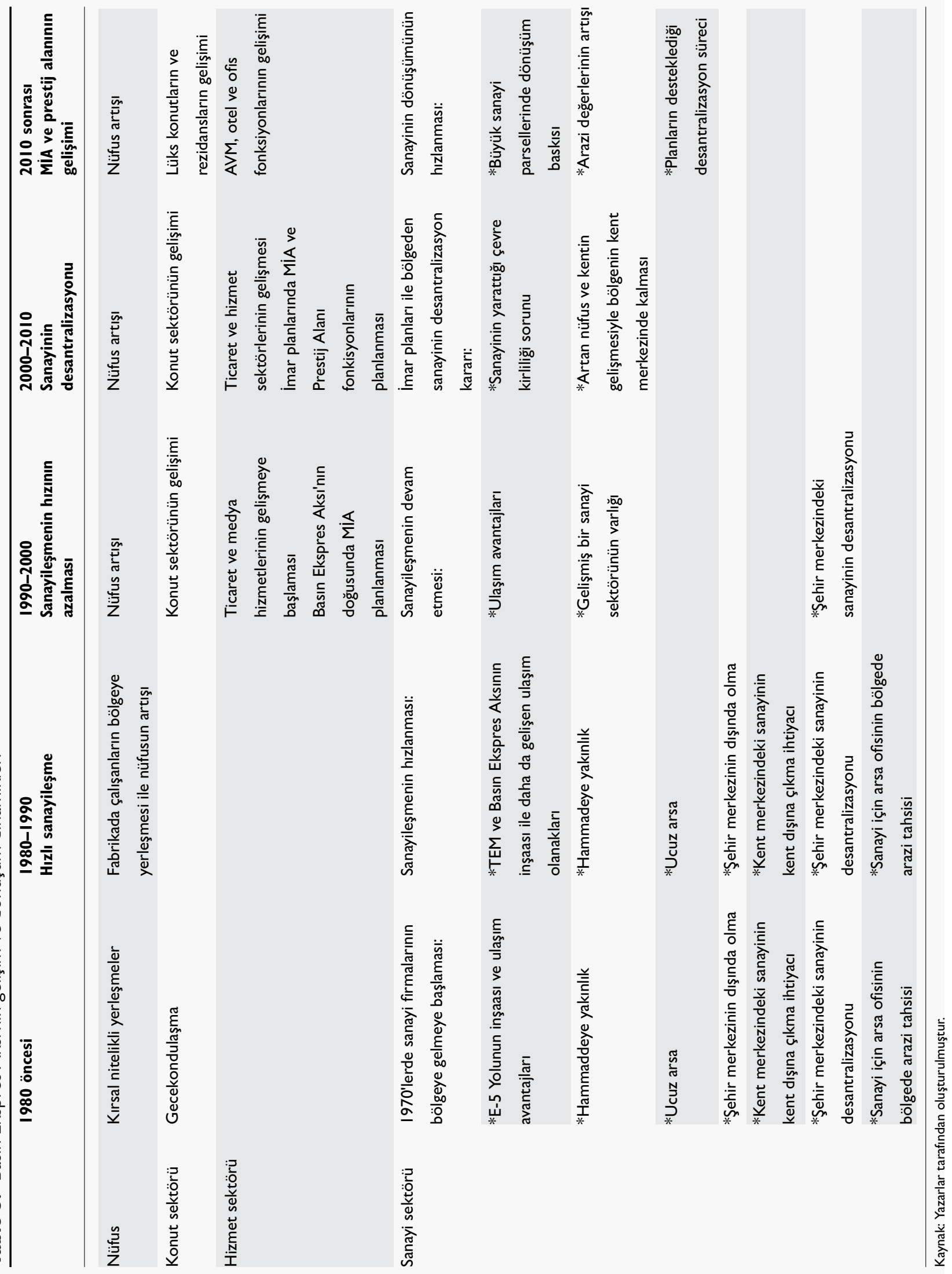


çıkarları doğrultusunda seçim yapmaktadır. Dolayısıyla dönüşümde piyasa koşulları etkili olmaktadır. Bu bulgu da Hutton (2004) ve Sacco ve Blessi (2009)'in kent merkezlerini piyasa güçlerinin şekillendirdiği yönündeki tezlerini desteklemektedir. Diğer yandan, Ak'ın (2008) ifade ettiği gibi, "yarışabilir" küresel sisteme adapte olabilmek için kentler ekonomik ve mekansal dönüşümler yaşamaktadır. Bu bağlamda, imar planlarında Basın Ekspres Aksı'nın uluslararası şirketlerin yer alması beklenen "Prestij Aksı" olarak adlandırılması, planlarda bu aksın "küresel sisteme eklemlenme" vurgusu, bölgenin ve kentin "yarışabilir" küresel sisteme adapte olabilme çabalarının bir parçası olarak değerlendirilebilir.

Bölgedeki dönüşüm süreci ile ilgili tartışılması gereken önemli bir nokta da bu alanlarda dönüşümün nasıl yapılması gerektiğidir. Bu soru ayrı bir araştırma konusudur. Sanayi alanlarının dönüşümü literatürde ilgi çeken konulardan birisidir. Ancak bu alanların dönüşümü için tek bir formül üretmek mümkün değildir. Her bölgenin dönüşümünün kendi içinde değerlendirilip ele alınması gerekir. Bu alanların hizmet bölgelerine, bilgi ve teknoloji temelli yenilikçi sektörlere ve konut alanlarına dönüşmesi çok yaygın bir yöntemdir. Bununla beraber dünyadaki örneklerde bu bölgelerdeki iş ve istihdam kayıpları önemli sorunlar olarak karşımıza çıkmaktadır. Ayrıca sanayi alanları kentsel dönüşüm süreçleri sonunda donatı alanları yetersiz, trafik problemleriyle mücadele eden yeni sorunlu alanlara da dönüşebilmektedir. Mommas (2004) bu bölgelerin üretim mekanlarından tüketim mekanlarına dönüşme riskinin altını çizmektedir. Halen üretken olan bir bölge üretkenliğini koruyarak nasıl dönüşebilir? Böylesine bir bölgede dönüşümün amacı, ilkeleri, politikaları ve araçları neler olmalıdır? Bu sürecin aktörleri kimlerdir? Sanayi ve hizmet sektörü nasıl dengeli şekilde planlanabilir? Basın Ekspres Aksı için de bu soruların cevaplarını arayacak araştırmalar hem yerel yönetimlerin uygulamalarına hem de literatüre önemli katkılar yapacaktır. Bu açıdan, sanayi alanlarının dönüşümü ile ilgili farklı senaryoların geliştirilerek bu senaryoların sürdürülebilirlik ilkesi çerçevesinde değerlendirilmesine yönelik çalışmalar önemli bir çerçeve sunabilir. 


\section{KAYNAKLAR}

Ak, B. (2008). Deindustrialization Under The Impact Of Globalization: The Case of Istanbul. (Unpublished master thesis). The Graduate School Of Natural And Applied Sciences of Middle East Technical University, Ankara.

Bağcılar Belediyesi (2004). Bağcılar İlçesi 1/1000 Ölçekli Revizyon İmar Planı Raporu, İstanbul.

Bağcılar Belediyesi (2008). İstanbul İli Bağcılar İlçesi 1/1000 Ölçekli Uygulama İmar Planı Açıklama Raporu, İstanbul.

Bell, D. (1976). The Coming of the Post-Industrial Society. The Educational Forum, 40 (4). 574-579.

Boyko vd. (2012). Benchmarking Sustainability in Cities: The Role of Indicators and Future Scenarios. Global Environmental Change, 22, 245-254.

Castells, M. (2005). Ağ Toplumunun Yükselişî. İstanbul: İstanbul Bilgi Üni versitesi Yayınları.

Clark, E. (1992). Osmanlı Sanayi Devrimi. Ekmeleddin İhsanoğlu (Ed.), Osmanllar ve Batı Teknolojisi, Yeni Araştırmalar, Yeni Görüşler içinde (s.37-52). İstanbul: İstanbul Üniversitesi Edebiyat Fakültesi Yayını.

Cohen, S., Zysman, J. (1987). Manufacturing Matters: The Myth of Postindustrial Economy. New York: Basic Books.

Dağ, H., Özberk, S. (2012). Eski Sanayi Kentlerinde Kentsel Dönüşümden Kültürel Dönüşüme: Ruhr Bölgesi Örneği. Kahramanmaraş Sütçü İmam Üniversitesi Sosyal Bilimler Dergisi, 9 (2), 147-166.

Delibaş, M. (2012). Critical Assement of 'Stream Daylighting' As An Approach For Renaturalization Of Riverine System In Urban Areas Case Study On: Ayamama Stream. (Yayınlanmamış yüksek lisans tezi). İstanbul Teknik Üniversitesi/Fen Bilimleri Enstitüsü, İstanbul.

Doğan, M. (2013). Geçmişten Günümüze İstanbul'da Sanayileşme Süreci Ve Son 10 Yillık Gelişimi. Marmara Coğrafya Dergisi, 1(27), 511-550.

Dörry, S., Rosol, M., Thissen, F. (2016). The Significance of Creative Industry Policy Narratives for Zurich's Transformation Toward a Post-industrial City. Cities, 58, 137-142.

DPT, (2000). Sekizinci Beş Yıllık Kalkınma Planı, Bölgesel Gelişme Özel İhtisas Komisyonu Raporu, Ankara.

Erkut, G., Albayrak, A. N. (2004). Sanayi Gelişimini Etkileyen Yerel Dinamikler: Gebze Dilovası Örneği. 11.Bölge Bilimi/Bölge Planlama Kongresi, 21-23 Ekim, Trabzon.

Ertin, G. (1998). Türkiye'de Sanayi. Nuray Serter (Ed.), Türkiye Coğrafyas içinde (s. 163-182). Eskişehir: Anadolu Üniversitesi Açıöğretim Fakültesi Yayınlar1.

Es, M., Güloğlu, T. (2004). Bilgi Toplumuna Geçişte Kentlileşme ve Kentsel Yoksulluk; İstanbul Örneği. Bilgi Sosyal Bilimler Dergisi, 1, 79-93.

Franz, M., Güles, O., Prey, G. (2008). Place-making and green reuses of brownfields in the Ruhr. Tijdschrift Woor Economische en Sociale Geografie, 99 (3), 316-328.

Günay, Z. (2014). The Golden Horn: Heritage Industry Vs. Industrial Heritage. Uludağ Üniversitesi Mühendislik Fakültesi Dergisi, 19 (2),97-108.

Gür, S., Türk, Ş., Ş. (2014). 6306 Sayılı Kanunla Yeniden Ortaya Çıkan Bina Ölçeğinde Kentsel Yenileme Pratiği: Bağcllar İlçesi Örneği. Dünya Şehircilik Günü 38.

Kolokyumu, 6-7-8- Kasım, İstanbul.

Hall, P. (1996). Cities of Tomorrow. Oxford: Blackwell.

Hall, P. (1997). Modelling the Post-Industrial City. Futures, 29, No. 4/5, 311 322.

Hall, T. (1998). Urban Geography, New York: Routledge.

Hemphill, L., Berry, J., McGreal, S. (2004). An Indicator-based Approach to Measuring Sustainable Urban Regeneration Performance: Part 1, Conceptual Foundation and Methodologial Framework. Urban Studies, 41(4), 725-755.

Hutton, T. A. (2004). Post-industrialism, Post-modernism and the Reproduction of Vancouver's Central Area: Retheorising the 21st-century City.
Urban Studies, 41 (10), 1953-1982.

İstanbul Büyükşehir Belediyesi (2009). 1/100.000 Ölçekli İstanbul Çevre Düzeni Planı Raporu, İstanbul.

İstanbul Büyükşehir Belediyesi (2013). 1/5000 Ölçekli Yenibosna Basın Aksı Revizyon Nazım İmar Planı Raporu, İstanbul.

İstanbul Kalkınma Ajansı. (2010). İstanbul Bölge Planı 2010-2013. İstanbul.

Korkmaz, H. (2013). Yerel Politikalarda Kentsel Dönüşüm Uygulamalar1: Kayseri İli Örneği. Yerel Politikalar, 4, 116-140.

Köksal, T.G., Ahunbay, Z. (2006). İstanbul'daki Endüstri Mirası için Koruma ve Yeniden Kullanım Önerileri. İTÜ Arı Dergisi, 5 (2), 125-136.

Küçükçekmece Belediyesi (2013). Küçükçekmece Yenibosna Basın Aksı 1/1000 Ölçekli Revizyon Uygulama İmar Plan Raporu, İstanbul.

Meçik, O., Afşar, M. (2015). Ekonomide Sanayisizleşme ve OECD Ülkelerine Etkileri. Hacettepe Üniversitesi İktisadi ve İdari Bilimler Fakültesi Dergisi, 33 (2), 85-111.

Mommaas, H. (2004). Cultural clusters and the post-industrial city: Towards the remapping of urban cultural policy. Urban Studies, 41 (3), 507-532.

Nurtekin, H., G. (2018). Kentin Sanayi Alanlarında yașanan Dönüșüm Süreçleri ve Dinamikleri; İstanbul Basın Ekspres Aksı Örneği. (Yayınlanmamış yüksek lisans tezi). İstanbul Arel Üniversitesi/Fen Bilimleri Enstitüsü, İstanbul.

Ocakçı, M. (1989). Metropolitenleşme Sürecinde İmalat Sanayi ve Metropoliten Şehir İlişkileri. (Yayınlanmamış doktora tezi). İTÜ/Fen Bilimleri Enstitüsü, İstanbul.

OECD, (2008). OECD Territorial Reviews: Istanbul, Turkey,ISBN 978-9264-04371-8.

Onur, A.C., Alp, J. (2018). 2000 Sonrasında İstanbul'da Konut Ağırlıklı Dönüssen Sanayi Alanları Üzerine Bir Değerlendirme. İstanbul 1. Konut Kurultayı, 10-11 Mayıs, İstanbul.

Olcay, G.,P. (2013). Hazır Giyim Sektörünün Uluslararası Üretim Coğrafyasının Biçimlenme Dinamikleri ve Bu Dinamiklerin İstanbul'a Etkileri. Planlama Dergisi, 23 (1): 26-34.

Öcal, G.,P. (2006). Trakya Bölgesi’nin Sanayileşme Dinamikleri ve Çorlu Sanayi Kümeleri. (Yayınlanmamış yüksek lisans tezi). İstanbul Teknik Üniversitesi/ Fen Bilimleri Enstitüsü, İstanbul.

Öktem, B. (2006). Neoliberal Küreselleşmenin Kentlerde inşası: AKP’nin Küresel Kent Söylemi ve İstanbul'un Kentsel Dönüşüm Projeleri. Planlama Dergisi, 2, 53-64.

Özcan, O., Musaoğlu, N. (2010). Flood Risk Analysis Using Information Diffusion Theory. 30th EARSeL Symposium: Remote Sensing for Science, Education and Culture, 31 May- 3 June, Paris, France.

Sacco, P., Blessi, G. T. (2009). The Social Viability of Culture-led Urban Transformation Processes: Evidence from the Bicocca District, Milan. Urban Studies, 46 (5, 6), 1115-1135.

Sazak, S. (2002). Metropoliten Kentin Etki Alanında Kalan Kentlerin Çeperindeki Arsaların Dönüşüm Süreci, Çorlu-Büyükkarıştıran Örneği. Edirne: Trakya Üniversitesi Rektörlüğü Yayınları.

Scott, J. W., Kühn, M. (2012). Urban change and urban development strategies in Central East Europe: A selective assessment of events since 1989. European Planning Studies, 20 (7), 1093-1109.

Serdaroğlu, S.(2011). Basın Ekspres Yolu: La Defense mı? Yoksa yeni bir Maslak mı?’. Gayrimenkul Yatırım İstanbul, 21, 57.

Slach O., and Boruta, T. (2012). What can cultural and creative industries do for urban development? Three stories from the post-socialist industrial city of Ostrava. Quaestiones Geographicae, 31(4), 99-112.

Sönmez, Ö. (2018). İstanbul Metropoliten Alan Planlamasında Uygulama Güçlükleri: Kartal Dönüşüm Projesi Deneğimi. Megaron, 13(3), 407 421.

Şahin, Ö. (2012). Eski Sanayi Alanları Dönüşümünde Ortaklık Modeli Önerisi: Kartal Örneği. (Yayımlanmamış doktora tezi). İstanbul Teknik Üniversitesi/ Fen Bilimleri Enstitüsü, İstanbul.

Tekeli, İ. (1994). The Development of Istanbul Metropolitan Area: Urban 
Administration and Planning. İstanbul: Kent Basımevi.

Temurçin, K., Aldırmaz, Y. (2017). İstanbul İlinde Sanayi: Tarihsel Gelişim, Yapısal Değişim, Mekansal Dönüşüm. Kadir Temurçin ve Murat Ali Dulupçu (Ed.), Türkiyéde Mekansal ve Bölgesel Dönüşümler içinde (s.114). Isparta: Süleyman Demirel Üniversitesi Yayınları

Tolga, H.,B. (2006). Endüstriyel Alanların Dönüşümü, Kentsel Mekana Etkileri: Beykoz Kundura ve Deri Fabrikası İçin Bir Dönüşüm Senaryosu. (Yayımlanmamış yüksek lisans tezi). Yıldız Teknik Üniversitesi/Fen Bilimleri Enstitüsü, İstanbul.

Tümertekin, E., Özgüç, N. (1997). Ekonomik Coğrafya. İstanbul: Çantay Kitabevi.

Tümertekin, E. (2014). İstanbul İnsan ve Mekân. İstanbul: Tarih Vakfı Yurt Yayınları.

Williams, K., Dair, C. (2007). A Framework for Assessing the Sustainability of Brownfield Developments. Journal of Environmental Planning and Management, 50 (1), 23-40.

Yerliyurt, B. (2008). Kentsel Kiyi Alanlarinda Yer Alan Sanayi Bölgelerinde Dönüşüm Stratejilerinin Değerlendirilmesi; Haliç - Tersaneler Bölgesi. (Yayımlanmamış doktora tezi). Yıldız Teknik Üniversitesi/Fen Bilimleri Enstitüsü, İstanbul.

Yüzer, A.Ş. (2002). Yerleşmelerde Sanayi Alanları Yer Seçimi Eğilimi Alan Tahsisleri ve Yeni Düzenleme Stratejileri İstanbul Örneği. (Yayımlanmamış doktora tezi). İTÜ/Fen Bilimleri Enstitüsü, İstanbul.

\section{Internet Kaynakları}

Edip Gayrimenkul. (t.y.). Erişim adresi: http://edip.com

Taşkın, G. (2013, 2 Temmuz). Yatırımın Yeni Gözdesi Basın Ekspres Yolu. Milliyet Gazetesi. Erişim adresi: http://www.milliyet.com.tr/konut/yatirimin-yeni-gozdesi-basin-ekspres-yolu-1730927

\section{Görüşme Listesi}

Görüşme 1: Halkalı Kağıt Karton Fabrikası, Çevre Sorumlusu (27.09.2018).

Görüşme 2: Bağcllar Belediyesi, Plan Proje Müdürlüğü, Planlama Müdürü (3.10.2018).

Görüşme 3: Makplast Plastik Fabrikası, Müdür Yardımcısı (28.09.2018).

Görüşme 4: Küçükçekmece Belediyesi, Plan Proje Müdürlüğü Planlama Şefi (30.10. 2018).

Görüşme 5: Remax Abc 2 Gayrimenkul Danışmanlık, Gayrimenkul Danış$\operatorname{man} 1$ (22.10.2018).

Görüşme 6: Maryapı Turizm İnşaat A.Ş., Kurumsal İletişim ve Pazarlama Sorumlusu (18.10.2018).

Görüşme 7: Bağcılar Belediyesi, Plan Proje Müdürlüğü, Şehir Plancısı (2007. 2010 y1llar1), (5.10.2018) 